Prepared in cooperation with The University of Arizona, School of Natural Resources and the Environment

\title{
Avian Community Responses to Juniper Woodland Structure and Thinning Treatments on the Colorado Plateau
}

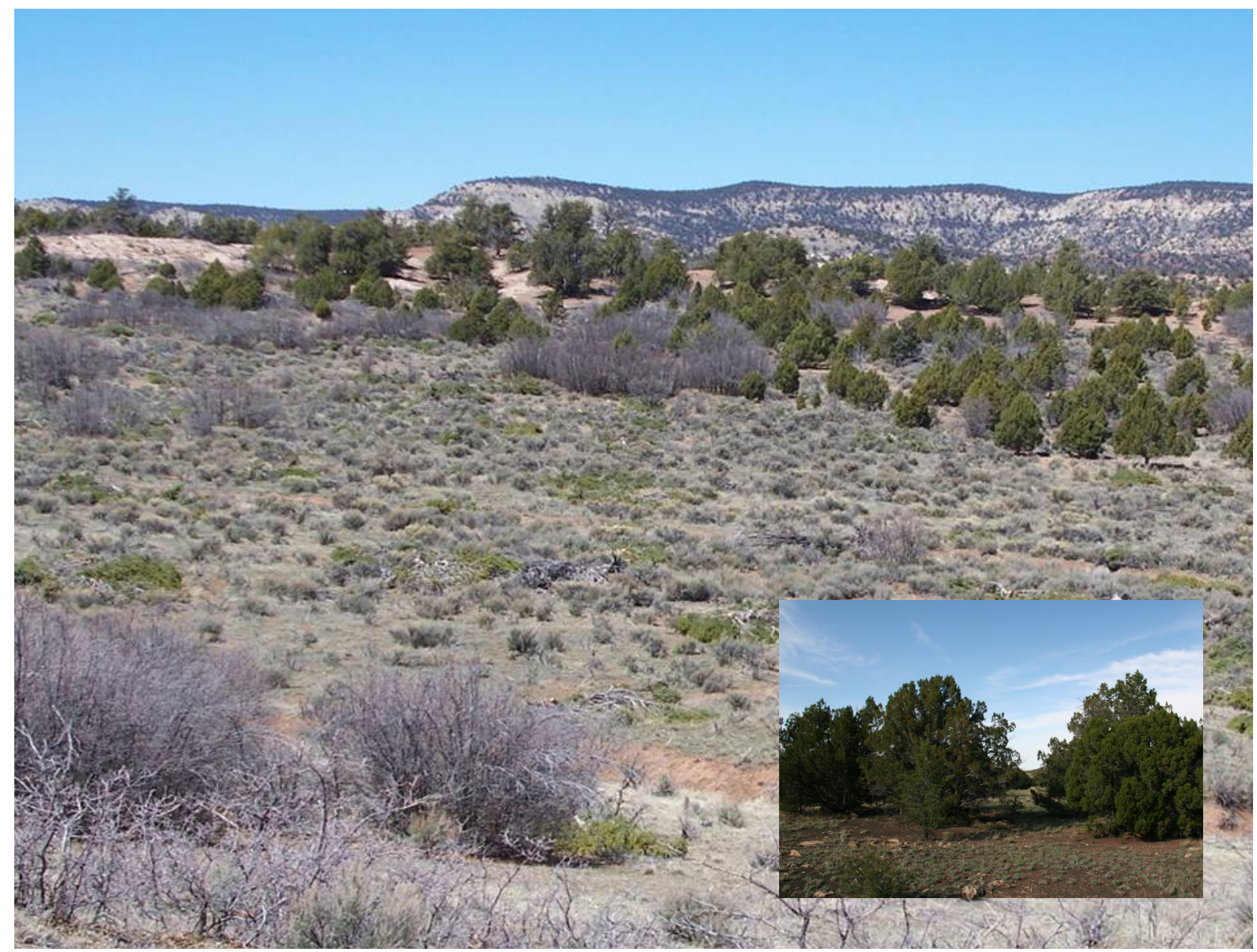

Open-File Report 2011-1109 
Cover: Ford Pasture, Grand Staircase-Escalante National Monument, Utah, following mechanical thinning of pinyon-juniper trees (photo by Claire Crow) and an inset (USGS photo by Charles van Riper III) showing the approximate condition of the pasture before treatment. 
Prepared in cooperation with The University of Arizona, School of Natural Resources and the Environment

\section{Avian Community Responses to Juniper Woodland Structure and Thinning Treatments on the Colorado Plateau}

By Claire Crow and Charles van Riper III

Open-File Report 2011-1109

U.S. Department of the Interior

U.S. Geological Survey 


\section{U.S. Department of the Interior \\ KEN SALAZAR, Secretary}

\section{U.S. Geological Survey \\ Marcia K. McNutt, Director}

U.S. Geological Survey, Reston, Virginia 2011

For product and ordering information:

World Wide Web: http://www.usgs.gov/pubprod

Telephone: 1-888-ASK-USGS

For more information on the USGS—-the Federal source for science about the Earth, its natural and living resources, natural hazards, and the environment:

World Wide Web: http://www.usgs.gov

Telephone: 1-888-ASK-USGS

Suggested citation:

Crow, Claire, and van Riper, Charles, III, Avian community responses to juniper woodland structure and thinning treatments on the Colorado Plateau: U.S. Geological Survey Open-File Report 2011-1109, 32 p.

[http://pubs.usgs.gov/of/2011/1109/].

Any use of trade, product, or firm names is for descriptive purposes only and does not imply endorsement by the U.S. Government.

Although this report is in the public domain, permission must be secured from the individual copyright owners to reproduce any copyrighted material contained within this report. 


\section{Contents}

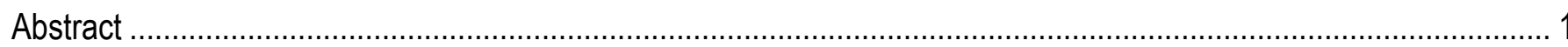

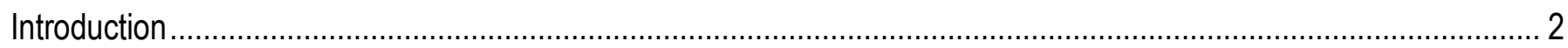

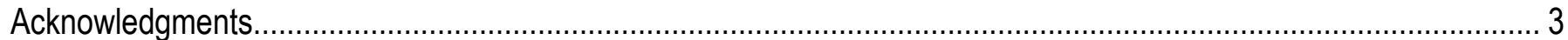

Avian Community and Vegetation Structure Relations in Areas of Fuels-Reduction Treatments in Pinyon-Juniper

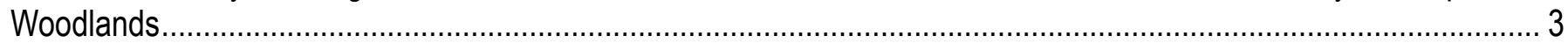

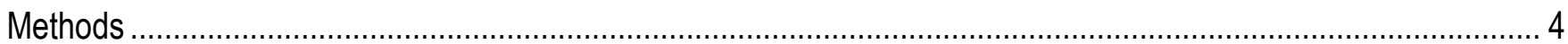

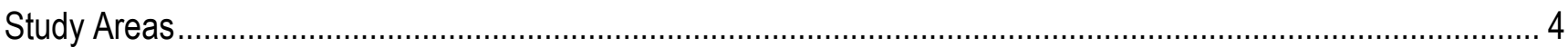

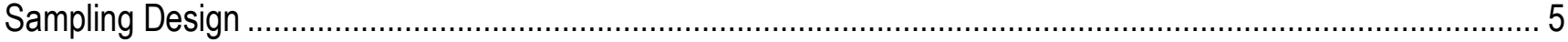

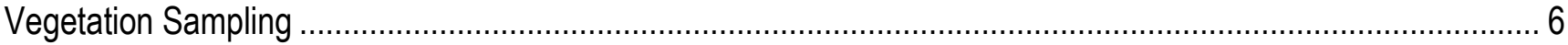

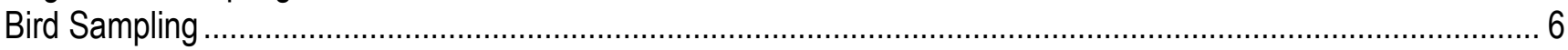

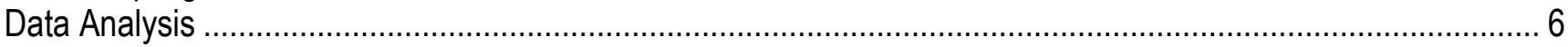

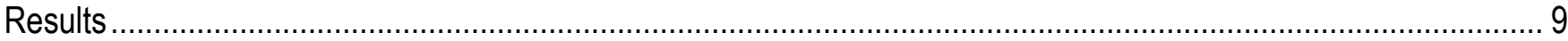

Bird-Vegetation Relations across Range of Natural Variation …………………………………………... 9

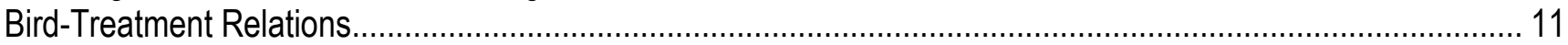

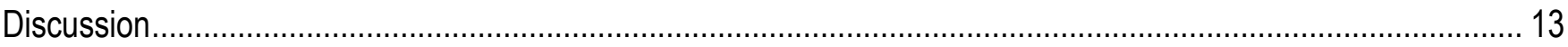

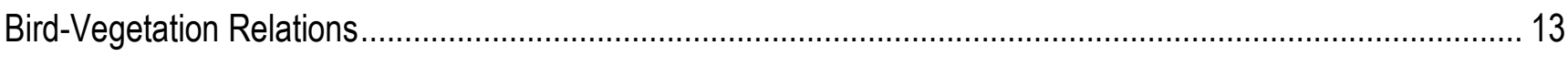

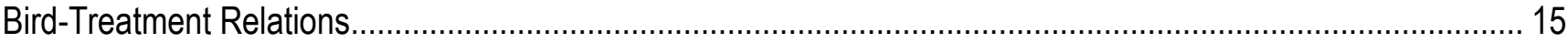

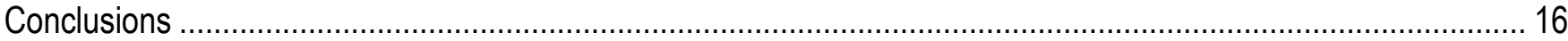

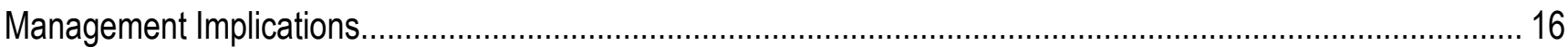

Avian Community Responses to Mechanical Thinning of a Pinyon-Juniper Woodland ............................................ 17

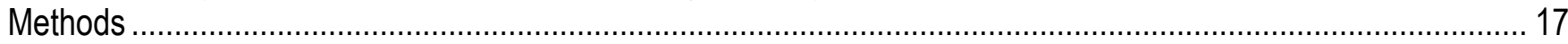

Study Area.

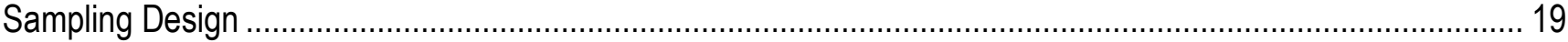

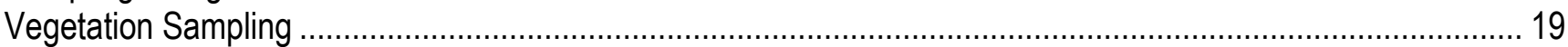

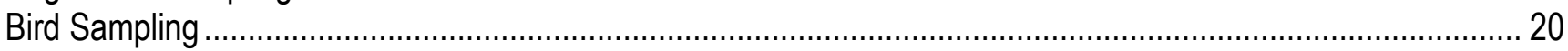

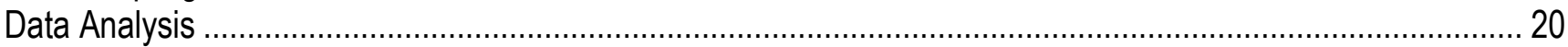

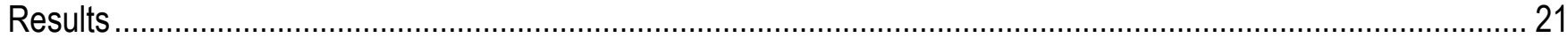

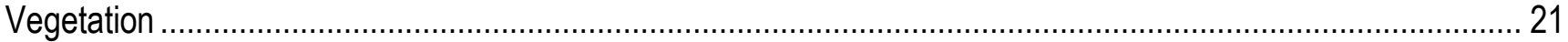

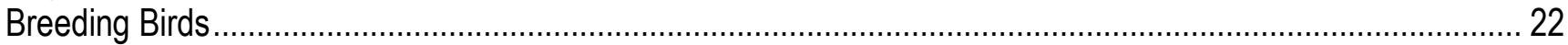

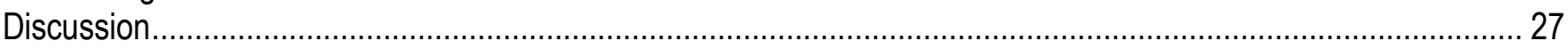

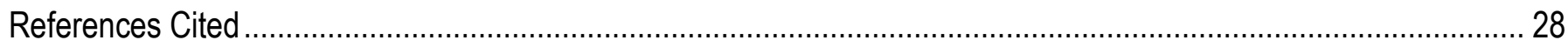

\section{Figures}

1. Three sites on the Colorado Plateau for which we modeled the relations between bird community and vegetation characteristics in pinyon-juniper woodlands.

2. Study area within Ford Pasture Fuels Reduction project area, Grand Staircase-Escalante National Monument, southern Utah 
3. Posttreatment mechanically thinned pinyon-juniper block, April 2006, Ford Pasture, Grand Staircase-

Escalante National Monument, Utah

\section{Tables}

1. Descriptions of three pinyon-juniper woodland sites on the Colorado Plateau at which we investigated bird-vegetation and bird-fuels reduction treatment relations during the 2005 and 2006 bird breeding seasons.

2. Bird species selected for modeling of relations between relative abundance and vegetation characteristics, with level of pinyon-juniper specialization and state of priority population status 7

3. Vegetation characteristics excluded from analysis because of low explanatory power or high correlation with other characteristics 8

4. Untreated plots: ranges and means of vegetation variables at three sites on the Colorado Plateau........ 9

5. Species richness: results of effects tests for relations to bird species richness for vegetation characteristics on 74 plots at 3 sites on the Colorado Plateau 10

6. Direction of relations with vegetation characteristics for bird species detected during 2005 and 2006 breeding seasons in pinyon-juniper woodlands across three sites on the Colorado Plateau 11

7. Chained plots: ranges and means of vegetation variables on chained plots at WACA and GSENM ..... 12

8. Hand-cut plots: ranges and means of vegetation variables in plots cut with chainsaws at WACA and GSENM. 12

9. Treatment method: relations with treatment method for relative abundance of six bird species detected during 2005 and 2006 breeding seasons on plots that had been treated by chaining, by hand-cutting, and control plots at GSENM and WACA

10. Change in tree (pinyon pine and juniper combined) characteristics on nine bird plots due to mechanicalthinning treatment. 22 
11. Avian species, U.S. Geological Survey Banding Laboratory alpha code, and number of detections on 20 plots in Ford Pasture Fuels Reduction project area, May-June 2005 and May-June 2006 23

12. Species richness (measured as total number of bird species) from pretreatment and posttreatment bird surveys on mechanical-thinning and control plots. 24

13. Site occupancy: summed AIC weights of occupancy probability $(\Psi)$ and detection probability $(p)$ covariates for avian species 25

14. Percent of control and treatment plots on which five species were detected before and after thinning of pinyon-juniper woodlands. 26

15. Mean difference in mean relative abundance and outcomes of two-sample t-tests for treatment effect on the mean difference in relative abundance (2006-2005) on control plots vs. the mean difference in relative abundance on treatment plots for pinyon-juniper specialists and other common species, by group and by species 


\title{
Avian Community Responses to Juniper Woodland Structure and Thinning Treatments on the Colorado Plateau
}

\author{
By Claire Crow ${ }^{1}$ and Charles van Riper III2
}

\begin{abstract}
Federal land managers are increasingly implementing fuels-reduction treatments throughout the western United States with objectives of ecological restoration and fire hazard reduction in pinyonjuniper (Pinus spp.-Juniperus spp.) woodlands. The pinyon-juniper woodland ecosystem complex is highly variable across the western landscape (Bock and Block, 2005; West and others, 1998), as is bird community composition (Balda, 1987).

We investigated relations between breeding birds and vegetation characteristics in modified pinyon-juniper woodlands at three sites (BLM, USFS, NPS) on the Colorado Plateau. During the breeding seasons of 2005 and 2006, we surveyed birds and measured vegetation in 74 study plots. These plots were each 3.1 hectares (ha; 7.6 acres), located across the range of natural variation, with 41 control sites and 33 plots in areas previously thinned by hand-cutting or chaining. We found that relations of avian pinyon-juniper specialists and priority species to vegetation characteristics were generally in agreement with the findings of previous studies and known nesting and feeding habits of those birds. Relatively high density of pinyon pines was important to species richness and abundance in 6 of 14 species. Abundance of all species was related to treatment method, and we found no difference in bird communities at chaining and hand-cut sites.

We also studied responses of breeding birds to mechanical reduction of pinyon-juniper woodlands scattered across sagebrush steppe in 11 control and 9 treatment plots at Grand StaircaseEscalante National Monument, Utah, in 2005 and 2006. We surveyed birds in 3.1-ha (7.6-acre) plots during the breeding season before and following treatment. Thinning in April 2006 removed a mean of 92 percent (standard error $=6.4$ percent) of the live trees from treatment plots. Two of 14 species, Gray Vireo (Vireo vicinior) and Brown-headed Cowbird (Molothrus ater), were not detected after thinning. Shrub-nesting birds, including sagebrush specialist Brewer's Sparrow (Spizella breweri), increased in relative abundance in treatment areas compared to controls. However, some species may exhibit a time lag in response, and further changes in community composition and abundance could result.

Our findings lend support to the concept that multiple small-scale fuels-reduction treatments, applied over the landscape, may provide the variety of successional stages needed to support a full assemblage of avian species in pinyon-juniper woodlands on the Colorado Plateau. Limiting scale and increasing precision of fuels-reduction projects in pinyon-juniper vegetation communities may maximize the benefits of management to both the pinyon-juniper and sagebrush steppe avian
\end{abstract}

\footnotetext{
${ }^{1}$ University of Arizona, School of Natural Resources and the Environment, Tucson, Arizona

${ }^{2}$ U.S. Geological Survey, Southwest Biological Science Center, Sonoran Desert Research Station, Tucson, Arizona
} 
communities. We conclude that small-scale fuels-reduction treatments can benefit many bird species while reducing fire risk and restoring an ecological balance.

\section{Introduction}

Pinyon-juniper (Pinus spp.-Juniperus spp.) woodlands are estimated to cover 24 to 40 million hectares (ha; 59 to 99 million acres) in the Intermountain West and are distributed extensively across the Colorado Plateau (Samuels and Betancourt, 1982). The distribution of these woodlands has expanded and contracted throughout history (Tausch, 1999), and expansion is presently occurring at a high rate (Miller and Wigand, 1994). Possible catalysts to this rapid expansion include historical fire suppression and livestock grazing (Harris and others, 2003; Johnsen, 1962; Miller and Rose, 1999; West, 1984), coupled with climate change (Bradshaw and Reveal, 1943; Gray and others, 2006). Recently, drought associated with climate change, coupled with bark-beetle infestations, have resulted in large areas of pinyon mortality (Breshears and others, 2005).

Land managers are increasingly implementing fuels-reduction treatments in pinyon-juniper woodlands with the goals of restoring habitat and reducing hazard fuels. Pinyon-juniper woodlands were historically maintained in an open, savannahlike state by fire, but as fire frequency has decreased because of suppression and livestock grazing, the resulting accumulation of fuels has shifted the fire regime to stand-replacing fires (Bock and Block, 2005; Harris and others, 2003, Miller and Rose, 1999; West, 1984). Federal land managers have been directed to apply fuels-reduction treatments to improve forest health while simultaneously reducing fire risk to surrounding development (U.S. Department of Agriculture Forest Service and Bureau of Land Management, 2004; U.S. Department of the Interior and U.S. Department of Agriculture Forest Service, 2006) and also to consider the effects of management actions on numerous ecosystem attributes (Brunson and Shindler, 2004; Clark, 1999; Dombeck, 1996), such as the status of neotropical migrant and other bird populations (U.S. Department of Agriculture Forest Service, 1994, 1996; U.S. Department of Agriculture Forest Service and U.S. Fish and Wildlife Service, 2001).

The pinyon-juniper woodland ecosystem complex is highly variable across landscapes (Bock and Block, 2005; West and others, 1998), and within western North America it includes 70 plant associations and 230 ecological site types (Moir and Carton, 1987). Pinyon-juniper woodlands may be dominated by either pinyon pines or junipers alone or by a combination of both. Associated shrubs, especially sagebrush (Artemisia spp.) and Gambel oak (Quercus gambelii), may also influence the dynamics of pinyon-juniper woodlands (Tausch and Hood, 2007). Even within a small area, considerable variation can exist. For example, the 16,000-ha (40,000-acre) pinyon-juniper vegetation complex at Zion National Park consists of three vegetation subtypes, further divided into nine recognized habitat types (Harper and others, 2003).

More than 70 species of birds breed in pinyon-juniper woodlands, but avian community composition varies considerably among woodlands (Balda, 1987). Bird species identified as breeding solely in pinyon-juniper woodlands have been characterized as pinyon-juniper specialists (Pavlacky and Anderson, 2001). Avian communities respond to changes brought about by natural successional processes and also by management actions that alter succession in pinyon-juniper woodlands (Knick and others, 2005; Medin and others, 2000; Rosenstock and van Riper, 2001; Sedgwick, 1987). Because bird species which have restricted habitat requirements, or which use their habitats unevenly, are negatively impacted by loss of their specific habitat (Stauffer and Best, 1980), it is likely that pinyonjuniper reduction would impact pinyon-juniper specialists more than generalist species.

To identify, across a large range of natural variation, relations between vegetation characteristics that would likely be altered by fuels-reduction treatments in pinyon-juniper woodlands and concomitant 
bird species richness and abundance, we selected pinyon-juniper woodlands at three Federally managed locations on the Colorado Plateau. Study sites included Bureau of Land Management (BLM), National Park Service (NPS), and U.S. Department of Agriculture Forest Service (USFS) areas that had been previously hand-cut with saws or chained. Additionally, we conducted surveys before and after a handcutting treatment to determine immediate effects of the treatment on bird species richness, abundance, and occupancy.

In this report we examine the relations between vegetation characteristics and pinyon-juniper specialists, along with other priority bird species, across the range of natural variation at three sites. Although two of the study sites were juniper-dominated and the third was dominated by a mix of pinyon pines and junipers, there were more positive relations with pinyon pine density than with juniper density. Relatively high pinyon pine density was important to insect consumers, including those that do not obtain prey directly from trees. It is possible that high foliage mass of pinyon pines provides not only foliage insects, as proposed by Laudenslayer and Balda (1976), but also increased cover in comparison to junipers.

\section{Acknowledgments}

We are indebted to many people for their assistance, without which this project would not have been completed. The support of Zion National Park, especially Henry Bastian, Jeff Bradybaugh, Kelly Fuhrmann, Kristin Legg, and Janet Passek, is appreciated. We also thank Grand Staircase-Escalante National Monument, Walnut Canyon National Monument, and Coconino National Forest for providing study sites and support. Elena Robisch and Cynthia Wanschura of Zion National Park supplied patient GIS guidance. We also thank Melissa Siders, Holly Beck, David Sinton, and Matthew Betenson of Grand Staircase-Escalante National Monument, all of whom provided assistance and direction. Sarah Gaines, Alyssa House, Rebecca Lieberg, Donna Shorrock, and John Duhamel provided invaluable assistance with field work. We are indebted to Patty and Phil Guertin, Mickey Reed, and the other members of the University of Arizona's Advance Resource Technology (ART) lab for their guidance.

We thank Robert J. Steidl and R. William Mannan for serving on Claire Crow's thesis committee, for their support and encouragement, and for providing a framework that became the foundation of this study. We also thank David B. Walker and Joan Fields for their encouragement. We are especially grateful to Chris O'Brien, Kathi Borgmann, and Karla Pelz-Serrano for advice. Additionally, we thank T.J. Fontaine, Glenn Johnson, Alyssa Rosemartin, and Tiffany Harvey for taking the time to review draft manuscripts of this work.

\section{Avian Community and Vegetation Structure Relations in Areas of Fuels- Reduction Treatments in Pinyon-Juniper Woodlands}

Pinyon-juniper woodlands were historically maintained in an open, savannahlike state by fire. But as fire frequency has decreased (mainly because of fire suppression and livestock grazing), older trees have died from drought and pine-bark beetle infestations (Breshears and others, 2005), and the resulting accumulation of fuels has shifted the fire regime to stand-replacing fires (Bock and Block, 2005; Harris and others, 2003; Miller and Rose, 1999; West, 1984). Therefore, it is important to consider how change in vegetation structure caused by fuels-reduction treatments might be expected to produce change in avian communities of treated pinyon-juniper woodlands.

Contemporary methods of fuels reduction include various mechanical treatments, prescribed fire, or a combination of mechanical treatments followed by prescribed fire (Shindler, 2004). There is considerable variation in the intensity of prescribed fires, equipment used for mechanical treatments (for 
example, chainsaws, wood shredding machines, chains), and disposition of felled trees. After falling, trees may be left, broadcast burned, removed, chipped and mulched on site, or piled and burned. Each of these methods might be expected to yield different modifications to vegetation, thus resulting in different changes to the avian community.

We selected pinyon-juniper woodlands at three Federally managed locations on the Colorado Plateau in order to investigate variation in vegetation and avian communities and avian-vegetation relations across a wide geographic range. The objectives of this study were to (1) identify, across a large geographic range, relations between vegetation characteristics and bird species richness and abundance that would likely be altered by fuels-reduction treatments in pinyon-juniper woodlands and (2) determine whether bird species richness or abundance differ by method of treatment in areas previously thinned by hand-cutting or chaining.

\section{Methods}

\section{Study Areas}

We selected three study areas, all managed by Federal agencies (fig. 1), to represent pinyonjuniper woodlands over the Colorado Plateau. Our sites were located in Walnut Canyon National Monument and the adjacent Coconino National Forest lands (WACA) in Arizona, and in Utah at Zion National Park (ZION) and Grand Staircase-Escalante National Monument (GSENM). Site descriptions are summarized in table 1 . Because environmental variables such as soils, aspect, and vegetation vary considerably in pinyon-juniper woodlands, we collected data on those variables at all three sites.

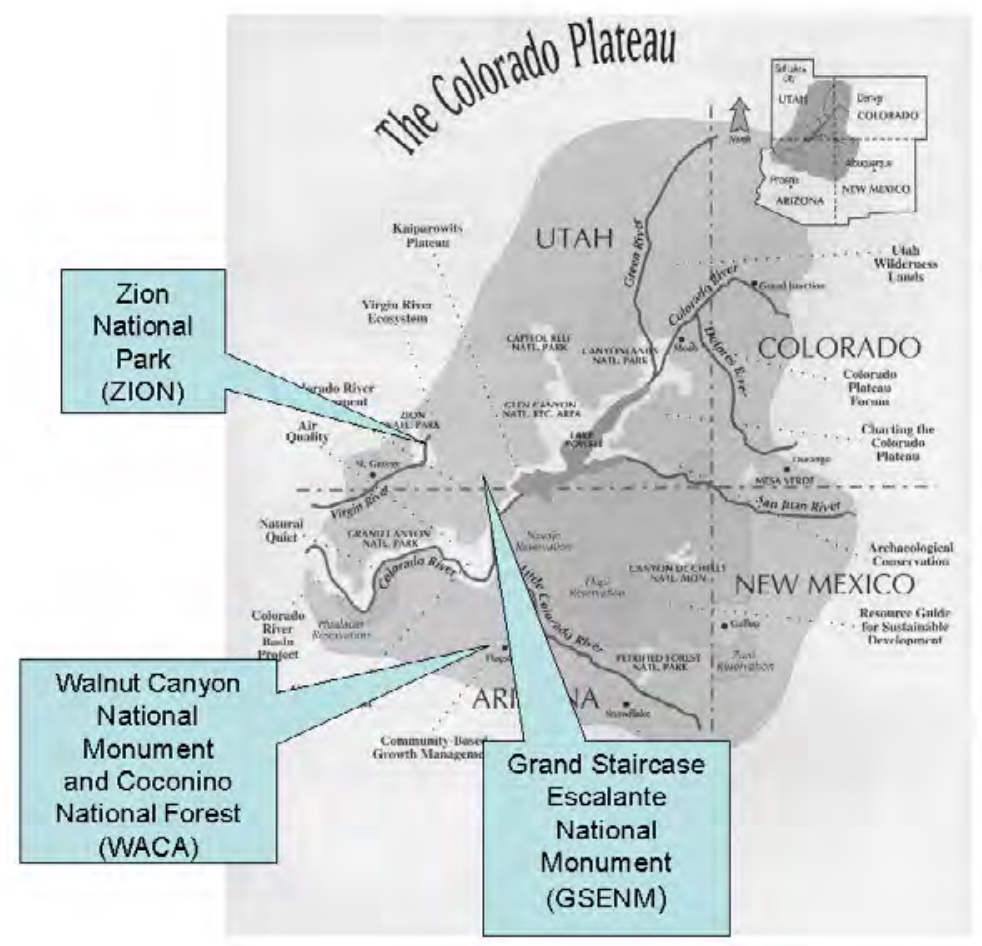

Figure 1. Three sites on the Colorado Plateau for which we modeled the relations between bird community and vegetation characteristics in pinyon-juniper woodlands. 
Table 1. Descriptions of three pinyon-juniper woodland sites on the Colorado Plateau at which we investigated bird-vegetation and bird-fuels reduction treatment relations during the 2005 and 2006 bird breeding seasons.

$[B L M=$ Bureau of Land Management; NPS = National Park Service; USDA Forest Service $=$ U.S. Department of Agriculture Forest Service; (-) = not applicable]

\begin{tabular}{|c|c|c|c|}
\hline & GSENM & WACA & ZION \\
\hline Administration & BLM & $\begin{array}{l}\text { NPS, USDA Forest } \\
\text { Service }\end{array}$ & NPS \\
\hline Latitiude & 37.04 & 35.17 & 37.3 \\
\hline Longitude & -112.49 & -111.51 & -113.05 \\
\hline State & Utah & Arizona & Utah \\
\hline Mean elevation, m & 2,000 & 2,000 & 2,000 \\
\hline $\begin{array}{l}\text { Annual precipitation, } \\
\mathrm{cm}\end{array}$ & 25 & 51 & 38 \\
\hline $\begin{array}{l}\text { Months of } \\
\text { precipitation }\end{array}$ & Nov-Mar & Jul-Oct, Dec-Mar & March-April, July-Sept \\
\hline $\begin{array}{l}\text { Dominant tree } \\
\text { species }\end{array}$ & Utah juniper & $\begin{array}{l}\text { Utah juniper, two- } \\
\text { needle pinyon pine }\end{array}$ & Rocky mountain juniper \\
\hline Secondary trees & $\begin{array}{l}\text { Two-needle pinyon } \\
\text { pine }\end{array}$ & - & $\begin{array}{l}\text { Ponderosa pine, two-needle } \\
\text { pinyon pine }\end{array}$ \\
\hline $\begin{array}{l}\text { Dominant shrub } \\
\text { species }\end{array}$ & Sagebrush & Antelope bitterbrush & Gambel oak \\
\hline Secondary shrubs & Rubber rabbitbrush & Rubber rabbitbrush & $\begin{array}{l}\text { Utah serviceberry, manzanita, } \\
\text { sagebrush }\end{array}$ \\
\hline Total no. bird plots & 45 & 28 & 34 \\
\hline No. plots chained & 8 & 8 & 0 \\
\hline No. plots hand-cut & 9 & 8 & 0 \\
\hline No. plots untreated & 28 & 12 & 34 \\
\hline
\end{tabular}

\section{Sampling Design}

We selected pinyon-juniper woodlands using vegetation layers in geographic information systems (ReGAP at GSENM, NPS-generated layers at WACA and ZION). To explore relations among birds and vegetation characteristics, we installed 74 plots across the range of natural variation at the three study sites. To investigate the effects of fuels-reduction treatment on bird species richness and abundance, we installed bird plots in areas that had previously been chained or hand-cut at GSENM and WACA (table 1). We generated random coordinates for locating bird count stations within each site, maintaining a minimum distance of $150 \mathrm{~m}$ between stations. Stations in treated areas were a minimum of $100 \mathrm{~m}$ from treatment boundaries. Those coordinates that occured on dangerously steep slopes and those located more than 30 min travel time from the closest already installed station were discarded. We navigated to each set of coordinates using handheld global positioning system (GPS) receivers and installed a rebar at each location to mark the count station. A bird plot was defined as a circular area of $100-\mathrm{m}$ radius centered on each station. 


\section{Vegetation Sampling}

Vegetation was measured during the summers of 2005 and 2006. Gambel oak (Quercus gambelii) was considered a shrub, which is its common form at our study sites. We based our vegetation sampling design on the protocol developed for the Breeding Biology Research and Monitoring Database (BBIRD) (Martin and others, 1997), with slight departures from that protocol. From each bird count station, we measured the distance to the nearest juniper, the nearest pinyon, and the nearest tree if a third species was closer, in each of four directions (NE, SE, SW, NW). Distances beyond $25 \mathrm{~m}$ were measured with handheld GPS receivers.

Four vegetation subplots were located $50 \mathrm{~m}$ from each of the bird count stations at the GSENM and WACA study areas, in each of the four cardinal directions (N, E, S, and W). For efficiency, we positioned the vegetation subplots $25 \mathrm{~m}$ from the bird count station at the ZION site, because of steep slopes and thick shrub cover. Within each subplot, we measured trees within a $15-\mathrm{m}$ radius and shrubs within a 5-m radius. We measured tree density by recording the total number of individuals, shrub density by the total number of stems. Diameter at breast height (DBH) was recorded for single-stemmed trees, diameter at root crown (DRC) for multistemmed trees. Diameter at stump height (ST), measured at 12 in. $(30.5 \mathrm{~cm})$ above the ground (Bradshaw and Reveal, 1943) was also recorded. All diameter measurements were made with a Biltmore stick held horizontal to the trunk. The trunks of some living junipers lay prone on the ground, but new growth occurred in what were originally horizontal branches; for these we measured height of the tallest "branch" and diameter at $30.5 \mathrm{~cm}$ along the main stem from the original root crown. For analysis, all diameter measurements were converted to diameter at root crown using the slope equation from logistic regressions of DBH and ST on DRC. We averaged vegetation measurements across the four vegetation subplots to describe vegetation characteristics per plot. A single observer performed all of the visual canopy cover estimates, in order to maintain consistency with data collection. No visual field estimates were performed at WACA; all canopy cover estimates for that site were based on digital orthophoto quadrangles (DOQs). In each vegetation plot, we estimated percent ground cover and percent cover of plants $<50 \mathrm{~cm}$ tall in a $1 \times 1-\mathrm{m}$ square. The square was located by selecting a distance between 0 and 5 meters, and an azimuth between 0 and 360 degrees, from a random numbers table.

\section{Bird Sampling}

We conducted bird counts at each station on five or six occasions during May and June, using variable circular plots (after Reynolds and others, 1980), truncated at 100-m maximum radius. Observers waited for $1 \mathrm{~min}$ upon arriving at each station before recording detections. We recorded all birds detected (visually or aurally) within the 100-m-radius bird plot over a 5-min period. Birds that flew over plots were not included. Visits to each bird plot were at 1-week intervals, with counts conducted between sunrise and 10 a.m. All surveys at the ZION and GSENM plots were conducted during the 2005 breeding season, with two observers alternating visits to minimize observer bias. In 2006, one observer conducted all surveys at WACA, the chained plots, and untreated plots at GSENM. No counts were conducted during rain or high winds. Sampling order was varied to minimize temporal bias.

\section{Data Analysis}

We used multiple linear regressions to explore relations of species richness and abundance to vegetation characteristics and treatment method (Ramsey and Schafer, 2002). Bird species richness was estimated by summing the number of species detected on each bird plot across all surveys, and all 63 
bird species were included in our species richness analysis. We calculated relative abundance at each plot as total number of detections divided by number of surveys. Selected species were categorized as pinyon-juniper specialists (Balda, 1987; Pavlacky and Anderson, 2001) and priority species in Utah (Parrish and others, 2002) or Arizona (Latta and others, 1999) for further analysis (table 2) and excluded species observed on fewer than five plots.

Table 2. Bird species selected for modeling of relations between relative abundance and vegetation characteristics, with level of pinyon-juniper specialization (PJ specific) (Balda and Masters, 1980) and state (UT, Utah; AZ, Arizona) of priority population status (Latta and others, 1999; Parrish and others, 2002).

$[\mathrm{PJ}$ specific $=$ level of pinyon-juniper specialization; specialist $=$ may nest in other vegetation communities; exclusive $=$ nests only in pinyon-juniper woodlands; UT = Utah; AZ = Arizona; $(-)=$ not a priority species]

\begin{tabular}{|c|c|c|c|c|}
\hline $\begin{array}{l}\text { Species } \\
\text { Code }\end{array}$ & Common Name & Scientific Name & PJ Specific & Priority \\
\hline ATFL & $\begin{array}{l}\text { Ash-throated } \\
\text { Flycatcher }\end{array}$ & $\begin{array}{l}\text { Myiarchus } \\
\text { cinerascens }\end{array}$ & specialist & - \\
\hline $\mathrm{BCHU}$ & $\begin{array}{l}\text { Black-chinned } \\
\text { Hummingbird }\end{array}$ & $\begin{array}{l}\text { Archilochus } \\
\text { alexandri }\end{array}$ & specialist & - \\
\hline BEWR & Bewick's Wren & $\begin{array}{l}\text { Thyomanes } \\
\text { bewickii }\end{array}$ & specialist & - \\
\hline BGGN & Blue-gray Gnatcatcher & Polioptila caerulea & specialist & - \\
\hline BRSP & Brewer's Sparrow & Spizella brewerii & - & UT \\
\hline BTYW & $\begin{array}{l}\text { Black-throated Gray } \\
\text { Warbler }\end{array}$ & $\begin{array}{l}\text { Dendroica } \\
\text { nigrescens }\end{array}$ & specialist & AZ, UT \\
\hline GRFL & Gray Flycatcher & $\begin{array}{l}\text { Empidonax } \\
\text { wrightii }\end{array}$ & exclusive & $A Z$ \\
\hline GRVI & Gray Vireo & Vireo vicinior & exclusive & - \\
\hline GTTO & Green-tailed Towhee & Pipilo chlorurus & specialist & - \\
\hline JUTI & Juniper Titmouse & $\begin{array}{l}\text { Baeolophus } \\
\text { ridgwayi }\end{array}$ & specialist & $A Z$ \\
\hline HOFI & House Finch & $\begin{array}{l}\text { Carpodacus } \\
\text { mexicanus }\end{array}$ & specialist & - \\
\hline NOMO & Northern Mockingbird & Mimus polyglottos & specialist & - \\
\hline SPTO & Spotted Towhee & Pipilo maculatus & specialist & - \\
\hline VESP & Vesper Sparrow & $\begin{array}{l}\text { Pooecetes } \\
\text { gramineus }\end{array}$ & specialist & - \\
\hline VIWA & Virginia's Warbler & $\begin{array}{l}\text { Vermivora } \\
\text { virginiae }\end{array}$ & - & UT \\
\hline WSJA & Western Scrub-jay & $\begin{array}{l}\text { Aphelocoma } \\
\text { californica }\end{array}$ & exclusive & - \\
\hline
\end{tabular}


To reduce the complexity of our models to correspond with sample sizes, and for examining relations of species richness and abundance to vegetation characteristics, we excluded vegetation characteristics that contributed relatively little explanatory power (table 3). Data were transformed where appropriate, and we also addressed multicollinearity by conducting a multivariate analysis of the explanatory covariables for each site. For covariables with a correlation factor $>0.75$, we excluded the variable with lower ecological or management value.

खananatiable 3. Vegetation characteristics excluded from analysis because of low explanatory power or high correlation with other characteristics.

[Non-pj = non-pinyon-juniper $]$

\begin{tabular}{ll}
\hline Category & \multicolumn{1}{c}{ Variable } \\
\hline Trees & $\%$ canopy cover \\
& $\%$ canopy pinyon pine and juniper \\
& $\%$ canopy non-pj trees \\
& Non-pj tree density \\
& Snag density \\
& Juniper height \\
& Pinyon pine height \\
& Juniper diameter \\
& Pinyon pine diameter \\
& Stem density of tall shrubs \\
& Stem density of short shrubs \\
& Density of small diameter $(<2.5 \mathrm{~cm})$ stems \\
Shrubs & Density of large diameter $(\geq 2.5 \mathrm{~cm})$ stems \\
\hline Ground cover & $\%$ bare ground \\
\hline
\end{tabular}

We considered the vegetation characteristics in our analyses in two groups: pinyon-juniper and other (non-pinyon-juniper) characteristics. Non-pinyon-juniper characteristics included density of live shrub stems, density of dead shrub stems, shrub species richness, percent ground cover of litter, percent ground cover of grass, and percent ground cover of forbs. Because of minimal existing theoretical guidance for selecting among shrub and ground cover variables for our regression models, we employed mixed stepwise regressions on those variables for each bird response variable, with the probability to enter the model fixed at 0.250 and the probability to be removed from the model fixed at 0.100 . We then fit a model for each bird species response variable with the selected characteristics and the following pinyon-juniper characteristics: juniper stem density, pinyon pine stem density, and mean height of pinyon pines and junipers combined. When the stepwise regression process selected none of the shrub or ground cover variables, we fit a model including only the pinyon-juniper variables, and compared that to the regression with no coefficients (intercept only model). We then modeled relations between bird responses and method of treatment in separate analyses for the two sites with treated areas. The treatment methods were chaining and hand-cutting. 
We used F tests to select between and among models. From the selected models, we identified and established the direction of relations between vegetation characteristics and bird community responses by considering all $p$-values $<0.09$ to indicate a significant relation. Because changes in vegetation characteristics resulting from fuels-reduction actions might have important long-term effects on avian communities, we chose to maximize the sensitivity of our analysis to potential relations. We defined the direction of a relation as being either positive, in which the response variable increased as the vegetation variable increased in value, or negative, in which the response variable decreased as the vegetation variable increased.

\section{Results}

\section{Bird-Vegetation Relations across Range of Natural Variation}

The ranges and means of vegetation variables on the untreated plots at each of the three sites were quite variable (table 4). Among the study areas, three unique tree species were found on plots exclusively at ZION: ponderosa pine (Pinus ponderosa) was found on 25 of the bird plots (74 percent, $\mathrm{n}=34$ ), white fir (Abies concolor) was on 8 (24 percent) of the plots, and Douglas fir (Pseudotsuga menzesii) on 1 plot ( 3 percent). Canopy cover of these non-pj species ranged from 0 to 28 percent (mean $=5$ percent, $\mathrm{SE}[$ standard error $]=1.0$ percent) at ZION.

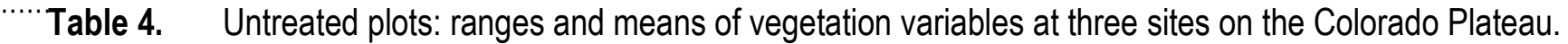
[SE = standard error; $\mathrm{PJ}=$ pinyon-juniper $]$

\begin{tabular}{|c|c|c|c|c|c|c|c|c|c|}
\hline \multirow{2}{*}{ Vegetation variable } & \multicolumn{3}{|c|}{ GSENM } & \multicolumn{3}{|c|}{ WACA } & \multicolumn{3}{|c|}{ ZION } \\
\hline & Range & Mean & SE & Range & Mean & SE & Range & Mean & SE \\
\hline Canopy cover (\%) & $0-26$ & 10 & 2.0 & $13-89$ & 57 & 5.4 & $2-22$ & 11 & 0.1 \\
\hline $\begin{array}{l}\text { Pinyon pine } \\
\text { density (trees/ha) }\end{array}$ & $0-136$ & 20 & 7.7 & $\begin{array}{r}230- \\
2168\end{array}$ & 1458 & 161.6 & $0-157$ & 36 & 7.6 \\
\hline $\begin{array}{l}\text { Juniper density } \\
\text { (trees/ha) }\end{array}$ & $0-220$ & 69 & 12.7 & $16-152$ & 102 & 11.3 & $20-140$ & 70 & 12.1 \\
\hline PJ height mean $(\mathrm{m})$ & $4-22$ & 10 & 0.5 & $6.5-14$ & 8.5 & 0.8 & 8-18 & 12 & 0.3 \\
\hline $\begin{array}{l}\text { Snag density } \\
\text { (snags/ha) }\end{array}$ & $0-60$ & 8 & 2.6 & $0-57$ & 30 & 5.0 & $0-11$ & 1 & 0.4 \\
\hline $\begin{array}{l}\text { Shrub density } \\
\text { (stems/ha) }\end{array}$ & $\begin{array}{l}44- \\
768\end{array}$ & 448 & 36.2 & $0-239$ & 79 & 22.9 & $\begin{array}{l}264- \\
1679\end{array}$ & 779 & 56.0 \\
\hline $\begin{array}{l}\text { Shrub species } \\
\text { richness (\# } \\
\text { species) }\end{array}$ & $1-4$ & 2 & 0.2 & $0-5$ & 2 & 0.4 & $2-7$ & 5 & 0.2 \\
\hline Grass $(\%$ cover $)$ & $0-51$ & 13 & 2.6 & $1-24$ & 10 & 0.2 & $0-50$ & 1 & 1.0 \\
\hline Forbs ( $\%$ cover $)$ & $0-10$ & 2 & 0.4 & $1-18$ & 7 & 1.4 & $0-35$ & 5 & 1 \\
\hline Litter ( $\%$ cover) & $7-89$ & 49 & 3.9 & $6-65$ & 32 & 6.0 & $33-100$ & 80 & 3.5 \\
\hline $\begin{array}{l}\text { Bare ground (\% } \\
\text { cover) }\end{array}$ & $6-93$ & 46 & 4.1 & $23-78$ & 51 & 5.0 & $0-68$ & 20 & 3.5 \\
\hline
\end{tabular}


Our analyses included the relation of 63 bird species with vegetation characteristics on 74 plots (table 5). Bird species richness on plots ranged from 4 to 20 species $(\bar{x}=11.8$ species, $\mathrm{SE}=0.31)$. Avian species richness was positively related to density of pinyon pines and shrub species and negatively related to live shrub density (table 5).

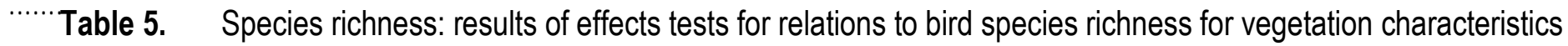
on 74 plots at 3 sites on the Colorado Plateau.

$[\mathrm{PJ}=$ pinyon juniper; relation direction: $\mathrm{P}=$ positive, $\mathrm{N}=$ negative, $(-)=$ no significant relation. $]$

\begin{tabular}{lcccc}
\hline \multicolumn{1}{c}{$\begin{array}{c}\text { Vegetation } \\
\text { characteristic }\end{array}$} & $\begin{array}{c}\text { Degrees } \\
\text { freedom }\end{array}$ & F Ratio & Prob > F & $\begin{array}{c}\text { Relation } \\
\text { direction }\end{array}$ \\
\hline Juniper density & 1 & 0.1728 & 0.6799 & - \\
Pinyon density & 1 & 7.7674 & 0.0082 & $\mathrm{P}$ \\
$\begin{array}{l}\text { PJ canopy height } \\
\text { Live shrub density }\end{array}$ & 1 & 0.0013 & 0.9718 & - \\
$\begin{array}{l}\text { Shrub species } \\
\text { richness }\end{array}$ & 1 & 3.3102 & 0.0765 & $\mathrm{~N}$ \\
\hline
\end{tabular}

${ }^{1}$ Percent cover of litter, grass, and forbs were excluded by step-wise regression analysis.

Of 14 bird species for which we had sufficient data to analyze abundance, the relative abundance of 7 species (50 percent) was positively related to one or more pinyon-juniper characteristics (table 6). Of seven bird-species relations to pinyon pine density, six (86 percent) were positive, and one relation (20 percent, $n=5$ ) to juniper density was positive. Pinyon-juniper fuels-reduction treatments would likely affect bird species that prefer breeding habitat with relatively high density of these tree species. Six species (43 percent, $n=14$ ) were negatively related to shrub density. Relative abundance of seven species (50 percent) was related to ground cover. 
10000001Table 6. Direction of relations with vegetation characteristics for bird species detected during 2005 and 2006 breeding seasons in pinyon-juniper woodlands across three sites on the Colorado Plateau.

[Bird response measured as relative abundance. $\mathrm{P}=$ positive relation; $\mathrm{N}=$ negative relation; $(-)=$ no significant relation; juniper $=$ juniper density; pinyon $=$ pinyon pine density; $\mathrm{PJ}$ ht $=$ mean canopy height of pinyon pines and junipers; shrub $=$ density of shrub stems; shrub rich = shrub species richness; \% Litt = percent of ground cover litter; $\%$ Grass $=$ percent of ground cover grass; \% Forb = percent of ground cover forbs]

\begin{tabular}{lcccccccc}
\hline \multicolumn{1}{c}{ Species } & Juniper & Pinyon & PJ ht & Shrub & $\begin{array}{c}\text { Shrub } \\
\text { Rich }\end{array}$ & $\%$ Litt & $\begin{array}{c}\% \\
\text { Grass }\end{array}$ & $\%$ Forb \\
\hline ATFL & - & - & - & N & - & - & - & - \\
BCHU & - & P & - & - & - & P & - & - \\
BEWR & P & - & N & N & - & - & - & - \\
BGGN & - & - & - & P & - & - & N & - \\
BRSP & N & - & N & P & - & - & - & - \\
BTYW & - & P & - & - & - & - & N & - \\
GRFL & - & P & - & N & - & - & - & - \\
GTTO & - & - & N & - & P & P & - & - \\
JUTI & - & P & - & N & - & - & - & - \\
HOFI & N & P & - & N & - & - & - & - \\
NOMO & - & - & - & N & P & N & - & - \\
\hline
\end{tabular}

${ }^{1}$ See table 2 for scientific and common names.

\section{Bird-Treatment Relations}

The ranges and means of vegetation variables on the chained and hand-cut plots at each site are summarized in tables 7 and 8, respectively. Bird species richness was negatively related to both types of treatment at WACA $(\mathrm{F} 2,25=3.1400, \mathrm{p}=0.0607)$, while it did not differ among treated and untreated plots at GSENM. 


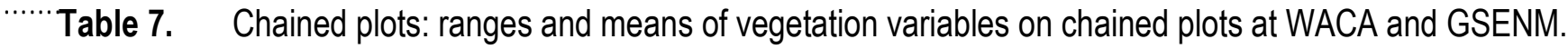
$[\mathrm{SE}=$ standard error; $\mathrm{PJ}=$ pinyon-juniper $]$

\begin{tabular}{l|rrr|rrr}
\hline \multirow{2}{*}{ Vegetation Variables } & \multicolumn{3}{|c|}{ GSENM } & \multicolumn{3}{c}{ WACA } \\
\cline { 2 - 7 } & Range & Mean & SE & Range & Mean & SE \\
\hline Canopy cover (\%) & $0-12$ & 35 & 16.8 & $0-20$ & 6 & 2.3 \\
Pinyon pine density (trees/ha) & $0-14$ & 8 & 0.5 & $0-230$ & 105 & 36.5 \\
Juniper density (trees/ha) & $0-116$ & 0 & 0.0 & $0-16$ & 7 & 2.6 \\
PJ height mean (m) & $6-10$ & 3 & 1.8 & $4-13$ & 6.5 & 1.6 \\
Snag density (snags/ha) & 0 & 1 & 0.3 & $0-7$ & 1 & 0.9 \\
Shrub density & $0-12$ & 1 & 0.4 & $37-297$ & 151 & 34.2 \\
Shrub species richness (\# & & & & & \\
$\quad$ species) & $1-3$ & 2 & 1.1 & $1-4$ & 2 & 0.4 \\
Grass (\% cover) & $0-4$ & 31 & 6.9 & $8-56$ & 30 & 5.4 \\
Forbs (\% cover) & $0-10$ & 66 & 7.6 & $1-13$ & 7 & 1.4 \\
Litter (\% cover) & $13-71$ & 35 & 16.8 & $4-30$ & 9 & 3.0 \\
Bare ground (\% cover) & $23-87$ & 8 & 0.5 & $32-79$ & 55 & 5.4 \\
\hline
\end{tabular}

[वasalatTable 8. Hand-cut plots: ranges and means of vegetation variables in plots cut with chainsaws at WACA and GSENM.

$[\mathrm{SE}=$ standard error; $\mathrm{PJ}=$ pinyon-juniper $]$

\begin{tabular}{l|rrr|rrr}
\hline \multirow{2}{*}{ Vegetation Variables } & \multicolumn{3}{|c|}{ GSENM } & \multicolumn{3}{c}{ WACA } \\
\cline { 2 - 7 } & Range & Mean & SE & Range & Mean & SE \\
\hline Canopy cover (\%) & $0-11$ & 1 & 1.2 & $7-42$ & 24 & 4.2 \\
Pinyon pine density (trees/ha) & $0-32$ & 4 & 3.6 & $0-1250$ & 670 & 169.9 \\
Juniper density (trees/ha) & $0-139$ & 16 & 15.4 & $0-88$ & 47 & 11.9 \\
PJ height mean (m) & $9-9.5$ & 9 & 0.1 & $4-9$ & 6.5 & 0.8 \\
Snag density (snags/ha) & $0-22$ & 4 & 2.5 & $0-23$ & 10 & 2.9 \\
Shrub density & $216-$ & & & & & \\
Shrub species richness (\# & 1419 & 618 & 117.6 & $21-439$ & 164 & 46.7 \\
$\quad$ species) & $1-3$ & 2 & 0.3 & & & \\
Grass (\% cover) & $0-51$ & 17 & 5.3 & $13-41$ & 21 & 0.0 \\
Forbs (\% cover) & $0-9$ & 3 & 0.9 & $0-20$ & 6 & 2.4 \\
Litter (\% cover) & $7-81$ & 45 & 6.7 & $5-45$ & 5.1 & 20.0 \\
Bare ground (\% cover) & $15-93$ & 47 & 7.5 & $37-86$ & 54 & 5.6 \\
\hline
\end{tabular}

Relative abundance of five of six bird species was negatively related to chaining on at least one site (table 9), whereas two of six species were negatively related to hand-cutting. We had sufficient detections to compare between sites for only two species. Black-throated Grey Warbler was negatively related to both treatment types at both sites. Vesper Sparrow was negatively related at GSENM and positively related to chaining at WACA. Brewer's Sparrow was positively related to hand-cutting at 
GSENM, but we did not have sufficient detections at WACA to analyze for treatment differences at that site.

Table 9. Treatment method: relations with treatment method for relative abundance of six bird species detected during 2005 and 2006 breeding seasons on plots that had been treated by chaining, by hand-cutting, and control plots at GSENM and WACA.

[Direction of relation: $\mathrm{N}=$ negative, $\mathrm{P}=$ positive, $(-)=$ no relation; $(*)=$ insufficient data]

\begin{tabular}{l|llll|llll}
\hline \multirow{2}{*}{ Species $^{1}$} & \multicolumn{5}{|c|}{ GSENM } & \multicolumn{4}{c}{ WACA } \\
\cline { 2 - 9 } BEWR & Chain & p>F & Hand & p>F & Chain & p>F & Hand & p>F \\
BRSP & $*$ & $*$ & $*$ & $*$ & $\mathrm{~N}$ & 0.0009 & $*$ & $*$ \\
BTYW & $\mathrm{P}$ & 0.0515 & $\mathrm{P}$ & 0.0383 & $*$ & $*$ & $*$ & $*$ \\
GRFL & $\mathrm{N}$ & 0.0191 & $\mathrm{~N}$ & 0.0019 & $\mathrm{~N}$ & 0.0251 & $\mathrm{~N}$ & 0.0160 \\
JUTI & $*$ & $*$ & $*$ & $*$ & $\mathrm{~N}$ & $<0.0001$ & $\mathrm{~N}$ & 0.0579 \\
VESP & $\mathrm{N}$ & 0.0031 & & $*$ & $*$ & $*$ & $*$ & $*$ \\
\hline
\end{tabular}

${ }^{1}$ See table 2 for scientific and common names.

\section{Discussion}

\section{Bird-Vegetation Relations}

Bird species richness was positively related to pinyon pine density and negatively related to shrub density, which is consistent with findings that species richness increases with maturity of woodlands (Pavlacky and Anderson, 2004; Rosenstock and van Riper, 2001). We found that pinyon pine density, overall tree density, and pinyon pine foliage volume were all correlated with bird species richness, as did Balda (1987). Fuels-reduction treatments, limited to small sections of existing woodlands, increase structural diversity and have been found to result in increased avian species richness (Willson, 1974). However, vegetation complexity may be reduced, thus lowering species richness (Laudenslayer and Balda, 1976). Thus, indiscriminate thinning of pinyon pines and junipers could lead to decreased avian species richness.

Although two of our study sites were juniper dominated and the third was dominated by a mix of pinyon pines and junipers (table 1), we found more positive relations with pinyon pine than with juniper density. Insects were the preferred diet of most of the species positively related with pinyon pine density (67 percent, $n=6$ ) (Ehrlich and others, 1988). This is consistent with the findings of Laudenslayer and Balda (1976), who postulated that pinyon pine trees might provide more foliage insects than junipers because of the greater percentage of green foliage per individual tree. However, three ( 50 percent) of the insect consumers preferring areas of high pinyon pine density in the present study did not obtain their prey directly from trees. Black-chinned Hummingbird (Archilochus alexandri), Gray Flycatcher (Empidonax wrightii) and Western Scrub-jay (Aphelocoma californicus) all forage in the air and/or on the ground (Ehrlich and others, 1988). Gray Flycatchers search from a tree perch and catch insects near or on the ground (Ryser 1985). The noninsectivorous House Finch (Carpodacus mexicanus) gleans seeds from the ground as well as from foliage (Ehrlich and others, 1988). We surmise that the additional cover afforded by the higher foliage mass of pinyon pines contributes to the preference of some species for areas of high pinyon pine density. 
We found that the Black-throated Gray Warbler (Dendroica nigrescens) was associated with high tree density (Pavlacky and Anderson, 2001, 2004) and pinyon pine presence and density (Goguen and others, 2005; Keane and Morrison, 1999; Pavlacky and Anderson, 2001). Likewise, Juniper Titmouse (Baeolophus ridgewayii) was associated with high tree density (Pavlacky and Anderson, 2004) and preferred pinyon pines for foraging and nesting (Laudenslayer and Balda, 1976). In juniperdominated woodlands in Wyoming, the likelihood of Juniper Titmouse occurrence was 246 percent higher where pinyon pine was present (Pavlacky and Anderson, 2001). Juniper Titmouse, House Finch, and Western Scrub-jay are major pinyon pine seed consumers that contribute to dispersal and regeneration of this tree species (Balda, 1987). Western Scrub-jay and House Finch were negatively related to juniper density in the present study, which suggests a strong preference for pinyon pines over junipers. These two species might particularly benefit from selective fuels reduction resulting in a high ratio of pinyon pines to junipers. The positive relations that we found with pinyon pine density are in agreement with previous studies and known nesting and feeding habits of the bird species (Laudenslayer and Balda, 1976; Pavlacky and Anderson, 2001). Of the six species positively related to pinyon pine density, House Finch and Gray Flycatcher had negative relations to shrub density. Pavlacky and Anderson (2004) also noted that the preferred habitat of these species is mature woodlands with moderate juniper recruitment and low shrub cover.

The Black-chinned Hummingbird breeds in deciduous trees and shrubs (Wethington and Russell, 2003), which is contrary to the positive relation we found with pinyon pine density. Previous research has shown that this species travels farther than $200 \mathrm{~m}$ from the nest to forage and concluded that nesting density for this species should not be estimated by searching for nests solely where individuals were detected (Brown, 1992; Wethington and Russell, 2003). Thus, the relations that we modeled in the current study may reflect preferences in foraging habitat rather than for nest sites.

We found that the relative abundance of Green-tailed Towhees (Pipilio chlorurus) was negatively related to tree height. In Colorado, O'Meara and others (1981) found that this shrub-nester bred exclusively in chained areas rather than adjacent mature pinyon-juniper woodland, and Sedgwick (1987) found it negatively associated with canopy height. This is contrary to the findings of Pavlacky and Anderson (2004), who suggested that the discrepancy between their results and those of Sedgwick might be due to a historical association of Green-tailed Towhee with openings created by natural disturbance in mature woodlands with large trees. This preference for open areas, they suggested, led to a negative association with tree maturity through selection of open chained areas rather than untreated woodlands, as occurred in Sedgwick's study, and a positive association with tree maturity when sampled across the natural variation in an untreated woodland in which mature patches had more openings than patches of lower maturity (Pavlacky and Anderson, 2004). Our study also sampled across natural variation in untreated plots, but in the three widely separated woodlands we found that the relative abundance of Green-tailed Towhees was negatively related to tree height. Perhaps Pavlacky and Anderson (2004) considered habitat use relative to other bird species, whereas both Sedgwick (1987) and the present study considered habitat preferences of individual species. We suggest that Green-tailed Towhee favors openings regardless of the type of creating disturbance, and that other properties of the openings may be more important than tree characteristics. We also found positive relations between Green-tailed Towhee and species richness and litter cover, as did Sedgwick (1987).

Cavity nesters, which would be expected to prefer mature woodlands with high tree density, were negatively related to shrub density. Bewick's Wren (Thyomanes bewickii) and Juniper Titmouse were also positively related to juniper density. Although Bewick's Wren usually nests in cavities in deciduous trees or snags (Ehrlich and others, 1988), this species selected areas of higher canopy cover than other bird species in pinyon-juniper woodlands (Pavlacky and Anderson, 2001, 2004). In the 
present study, a pine beetle infestation on 96 percent of plots with Bewick's Wren detections (23 of 24 plots) and 83 percent of plots with Juniper Titmouse detections (20 of 24 plots) had killed many of the pinyon pines. These species may have nested in the snags and gleaned insects from the living junipers in the vicinity.

We found that Virginia's Warbler (Vermivora virginiae) was positively related with shrub species richness. In Utah, open pinyon-juniper woodlands are secondary to oak as breeding habitat for Virginia's Warbler (Parrish and others, 2002). This species breeds in patches of Gambel oak within pinyon-juniper woodlands in Zion National Park (Wauer, 1997). Virginia's Warbler is known to select dense understory for nesting and foraging (Parrish and others, 2002). Shrub species richness, Gambel oak, and litter cover were important to Virginia's Warbler on steep slopes in Colorado (Sedgwick, 1987). Virgina's Warbler was also positively related to litter cover in the present study.

In our study, the three species that fed on the ground were positively related to ground cover. All three species also nested on the ground at least part of the time. Previous studies have shown negative correlations between bare ground and Vesper Sparrow (Pooecetes gramineus) abundance and reproductive success (Reed, 1986; Wray and Whitmore, 1979).

Although Blue-gray Gnatcatcher (Polioptila caerulea) has been classified as a semi-obligate in pinyon-juniper woodlands (Balda, 1987), this species is generally associated with mature pinyon-juniper habitat (Ehrlich and others, 1988; James, 1971; Whitmore, 1975). Previous studies have found positive associations between Blue-gray Gnatcatcher and understory biomass, shrub density, shrub species richness, density of small trees, and snag density (Anderson and Shugart, 1974; Pavlacky and Anderson, 2001; Sedgwick, 1987). In our study, we found a positive relation with shrub density and a negative relation with grass cover. It is possible that this species acts as a semi-obligate only under certain circumstances. Perhaps the preferences of Blue-gray Gnatcatcher differed between woodland interior and edges (Pavlacky and Anderson, 2001). We suggest that these preferences may also vary among woodlands, and that the semi-obligate classification may only apply on a local scale.

Frequency of Brewer's Sparrow (Spizella brewerii), Vesper Sparrow, Western Scrub-jay, and House Finch were negatively related to juniper density. Both sparrows are ground feeders that nest on the ground or in shrubs, and prefer open woodland clearings, fields, and arid brushland (Ehrlich and others, 1988). In previous studies, Brewer's Sparrow selected open shrubby areas far from woodland edges (Hardy, 1945; Sedgwick, 1987) and was associated with low juniper cover, low tree maturity, high shrub cover, and greater understory height (Pavlacky and Anderson, 2004). In our study we found that Brewer's Sparrow was negatively related to tree height and positively related to shrub density. Vesper Sparrow was negatively related to pinyon pine density as well as juniper density. O'Meara and others (1981) also found that this species nested exclusively in chained areas and avoided adjacent mature pinyon-juniper woodland.

Western Scrub-jay and House Finch are major consumers of pinyon pine seed (Balda, 1987), and both had positive relations with pinyon pine density in the present study. These birds seem to prefer locations with a high ratio of pinyon pines to junipers. In Arizona, pinyon pines were used by these species more often than expected for foraging and for breeding, whereas juniper use was about equal to expectations based on tree volume (Laudenslayer and Balda, 1976).

\section{Bird-Treatment Relations}

Bird species richness, regardless of method of treatment, was lower in treated areas that averaged lower pinyon pine density then in untreated plots. At WACA, mean pinyon pine density was lower in treated than in untreated plots $(F 2,25=22.2, \mathrm{p}<0.0001)$. At GSENM, mean density of pinyon pines did not vary with treatment $(\mathrm{F} 2,42=1.4, \mathrm{p}=0.2637)$, and neither did species richness. We found 
that avian species richness was positively related to pinyon pine density in untreated plots across all three sites.

We found few relations between relative abundance of species and mechanical thinning treatment method. Of six species with significant relations, only two species were sufficiently abundant to allow comparison at multiple sites. The Black-throated Gray Warbler, which avoids chained areas and breeds nearly exclusively in adjacent mature woodlands (O'Meara and others, 1981; Sedgwick and Ryder, 1987), was negatively associated with both chaining and hand-cutting relative to untreated plots in our study. We found the relation between Vesper Sparrow abundance and chaining to be negative at GESNM and positive at WACA. This bird species usually avoids treatment edges, breeding only in the interior of chained areas (O'Meara and others, 1981). It is possible that our random location of plots did not adequately represent the core of treatment units at GSENM, although none of our treatment plots at either site was closer than $100 \mathrm{~m}$ to treatment boundaries.

We found that relations did not differ in direction between treatment method and within a site for any bird species. However, small sample sizes in treated areas may have limited the number of significant relations between treatment method and bird relative abundance found in this study.

\section{Conclusions}

Although pinyon-juniper woodlands and their avian communities vary considerably across the landscape (Balda and Masters, 1980), increasing use of fuels-reduction treatments makes it vital to identify indicators of potential impacts that these treatments could have on bird populations. Across a wide geographic range of pinyon-juniper habitats, we found a strong relation between avian pinyonjuniper specialists and the presence of mature trees.

Although this study focused on bird species that used pinyon-juniper woodlands during the breeding season, several bird species are known to depend on pinyon-juniper woodlands in the fall and winter. Flocks of Pinyon Jays (Gymnorhinus cyanocephalus) were observed in our study but not included in analysis because they were detected only in flight. Townsend's Solitaire (Myadestes townsendi) feeds nearly exclusively on juniper fruits in winter (Poddar and Lederer, 1982), and Juniper Titmouse is known to eat juniper fruits in the fall (Latta and others, 1999). Thus, both breeding and wintering bird requirements should be considered when undertaking fuels-reduction treatments in pinyon-juniper habitats.

We recognize that the relations found in our models were simplifications of the many ecological interactions that likely took place. But by including three sites with varying vegetation attributes across a wide geographic range, we believe that we have captured the general influences of fuels-reduction management actions on avian community structure. By modeling relations between vegetation characteristics of habitat and bird species frequency and richness at the scale of 3.1 ha, we feel that the scale realistically represents proximal cues used in habitat selection for many avian species.

\section{Management Implications}

Avian communities in pinyon-juniper woodlands include species that prefer mature woodlands, areas of high tree density, and shrubby openings. Pinyon-juniper woodlands were historically maintained by fire, and given the lack of fire over the past century, active management is now required to sustain the variety of successional stages that are needed to support a full assemblage of avian species. The bird-vegetation relations that were evident in our study can be used as a basis to inform management decisions regarding benefits and drawbacks of implementing fuels-reduction treatments in pinyon-juniper woodlands. Management objectives will, however, ultimately influence decisions such as when to apply a treatment and what method to use. 
Reduction of pinyon pine density over large areas should be carefully considered because of the positive relations that exist with abundance of pinyon-juniper specialist birds, as well as the relation with avian species richness. Pavlacky and Anderson (2001) have shown that the distribution of pinyonjuniper specialists can be limited by the presence of pinyon pine near the boundary of the geographic range of these bird species. Planning and implementation of selective hand-cutting can ensure that a large proportion of mature pinyon pines are left standing. However, this management action is also labor intensive and expensive. A survey of Federal land managers found that mechanical treatments took 12 times as much effort to treat one-third the area of prescribed fire (deHoop and others, 2006). Unlike mechanical treatments, fire plays a role in nutrient cycling and stimulates sprouting and fruiting (Bock and Block, 2005). Application of prescribed fire in a mosaic of small treatments would also leave pockets of high-density pinyon pine.

Ecological restoration of pinyon-juniper woodlands may involve the decline of some avian species, while enhancing habitat for others. Woodland ecosystems and bird populations have been affected by altered fire regime (Bock and Block, 2005), and present avian assemblages may not represent the composition and distribution of healthy pinyon-juniper bird communities. If selective cutting is used initially to reduce fuel density and ladder fuels, the risk of stand-replacing crown fires will be reduced. This may require a series of smaller scale treatments. Prescribed fire can then mimic natural fires, which historically maintained healthy woodlands with openings that contribute to the diversity of avian habitat provided by pinyon-juniper woodlands. Once restoration goals are obtained, natural ignition wildfires could be allowed to burn within the woodland. This process would reduce risk to adjacent properties and resources and eventually restore a natural fire regime that maintains space between mature trees and preserves woodland openings, thus maximizing the number of avian species for which habitat is provided.

\section{Avian Community Responses to Mechanical Thinning of a Pinyon-Juniper Woodland}

Land managers are implementing fuels-reduction treatments in pinyon-juniper woodlands at an increasing rate, with the goals of habitat restoration and hazard fuels reduction. In the past, fire and chaining were used to remove colonizing junipers and pinyon pines. Following those removal efforts, pinyon pines and junipers have reemerged in chained areas on sagebrush steppes and grasslands, necessitating retreatment over the Colorado Plateau. Currently, managers are more frequently utilizing hand-cutting methods in place of chaining and prescribed fire.

The objectives of this study were to (1) describe the vegetation and breeding bird populations on a sagebrush steppe with scattered pinyon-juniper woodland, (2) assess the effects of mechanical pinyonjuniper reduction on bird species richness, abundance and avian community composition, and (3) provide information to aid managers in balancing benefits to pinyon-juniper and sagebrush steppe avian communities when undertaking fuels-reduction treatments.

\section{Methods}

\section{Study Area}

Our study area was located in Grand Staircase-Escalante National Monument (GSENM), a 688,000-ha (1,700,000-acre) unit in southern Utah, administered by the Bureau of Land Management (BLM). The Ford Pasture Fuels Reduction project area (hereafter called "Ford Pasture") is in the southwest corner of the Monument, off roads 601 and 602 in Johnson Canyon, about $30 \mathrm{~km}$ northeast of 
Kanab, Utah (fig. 2). The climate is arid, with the majority of the $25 \mathrm{~cm}$ of annual precipitation falling between November and March.
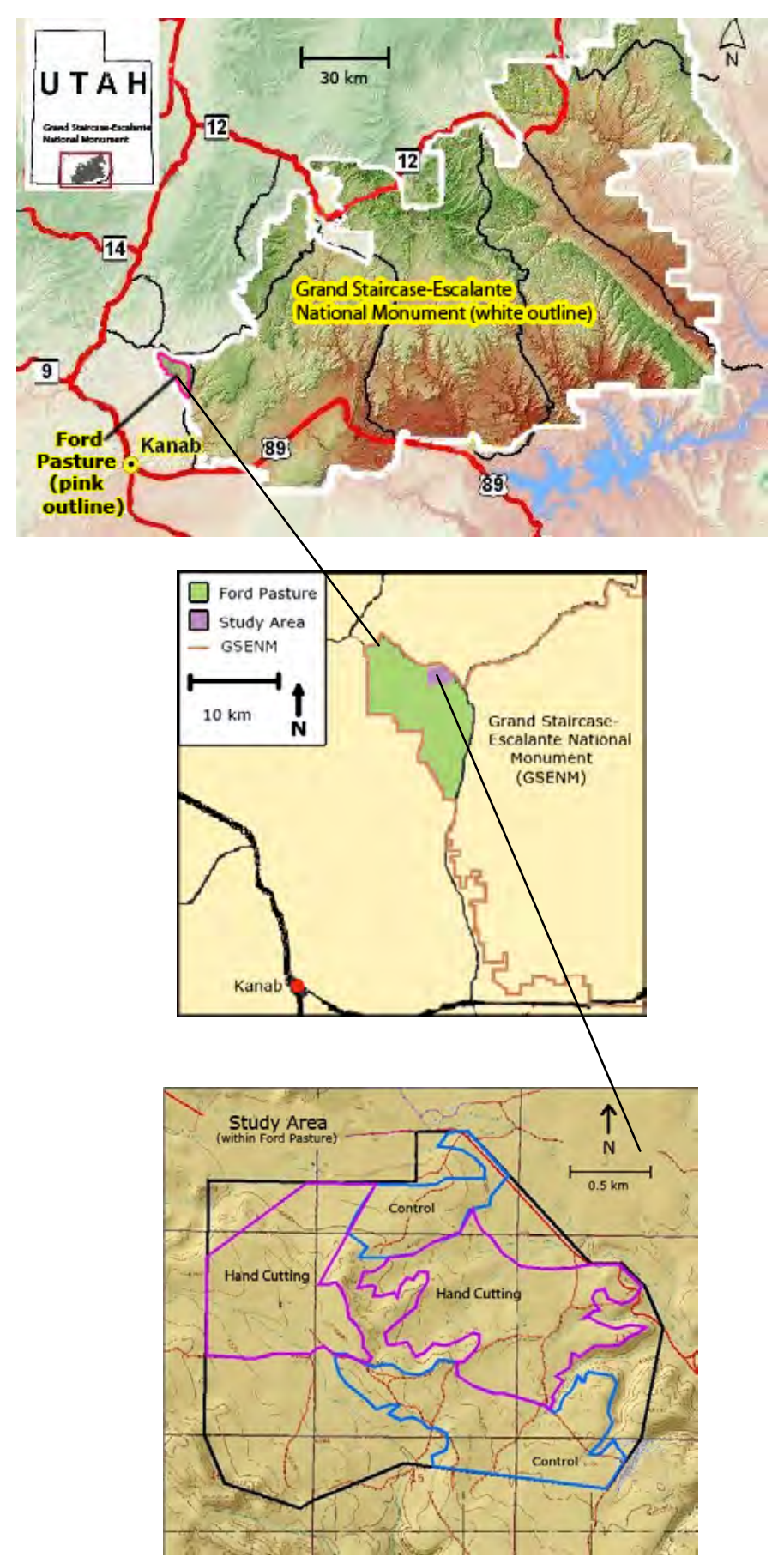

Figure 2. Study area within Ford Pasture Fuels Reduction project area, Grand Staircase-Escalante National Monument, southern Utah. 
Ford Pasture is at an elevation of 2,000 $\mathrm{m}$ on a sagebrush (Artemisia tridentata) steppe with scattered pinyon-juniper woodlands. Dominant trees are Utah juniper (Juniperus osteosperma) and twoneedle pinyon pine (Pinus edulis), although these are distributed patchily in the relatively flat sagebrush-dominated areas. Small higher density pinyon-juniper woodlands are on the surrounding low hills. Tall shrub species include Gambel oak (Quercus gambelii) and Utah serviceberry (Amelanchier utahensis). Rubber rabbitbrush (Chrysothamnus nauseosus) and occasional patches of sticky-leaved rabbitbrush (Chrysothamnus viscidifloris) are scattered among Great Basin big sagebrush (Artemisia tridentata). Herbaceous plants include daisies (Erigeron spp.), lupines (Lupinus spp.), and globe mallow (Sphaeralcea ambigua), with the following grasses: crested wheatgrass (Agropyron christatum), needleand-thread grass (Stipa comata), Indian ricegrass (Orhyzopsis hymenoides), Elymus spp., cheatgrass (Bromus tectorum), and six-weeks fescue (Festuca octaflora).

\section{Sampling Design}

Grand Staircase-Escalante National Monument personnel divided the 323-ha (959-acre) Ford Pasture into four units, two of which were assigned to mechanical thinning by hand-cutting (lop and drop) and two for controls. In 2005, before treatment, we installed 20 bird count stations in Ford Pasture. The treatment units contained five and four plots, and the control units contained six and five plots. In each of the units, we navigated to randomly generated coordinates using handheld GPS receivers and installed rebar at that location to mark the point count station. We discarded all coordinates within $100 \mathrm{~m}$ of a unit boundary and maintained a minimum $200 \mathrm{~m}$ between stations. We defined a 100-m-radius circle centered on each station as a bird plot.

\section{Vegetation Sampling}

Vegetation was measured on all plots in July and August 2005. Gambel oak was treated as a shrub, which is its common form on the study site. We repeated vegetation measurements on all plots in the mechanically thinned units during May and June 2006.

Vegetation sampling design was based on the BBIRD Protocol (Martin and others, 1997); here we discuss departures from that protocol. From each bird count station, we measured the distance to the nearest juniper, the nearest pinyon, and the nearest tree if a third species was closer, in each of four directions (NE, SE, SW, NW). The nearest trees were found by walking in a spiral pattern from the point. Distances beyond $25 \mathrm{~m}$ were measured with handheld GPS receivers.

Four vegetation subplots were located $50 \mathrm{~m}$ from the bird count station in each of the cardinal directions (N, E, S, W). In each subplot, we counted individual trees within a 15-m radius and shrub stems within a 5-m radius. Diameter at breast height (DBH) was recorded only for single-stemmed trees; diameter at root crown (DRC) was recorded for multistemmed trees. Diameter at stump height (ST) was measured $30.5 \mathrm{~cm}$ above the ground (Bradshaw and Reveal, 1943). All diameter measurements were made with a Biltmore stick held perpendicular to the trunk. For living junipers whose main trunk lay prone on the ground, we measured the height of the tallest "branch." We measured the diameter (approximating DBH) of these trees at what we estimated to be $30.5 \mathrm{~cm}$ along the main stem from the original root crown. For analysis, all diameter measurements were converted to diameter at root crown using the slope equation from logistic regressions of DBH and ST on DRC. We determined tree maturity classes following Bradshaw and Reveal (1943). One person estimated canopy cover visually for all plots. We verified the accuracy of the pretreatment field estimates of canopy cover by comparing them with estimates derived from aerial images (digital orthophoto quadrangles, or DOQs). We used an overlay grid of 10x10-m cells to calculate canopy cover of each bird plot (no. cells, 
to the nearest quarter cell, covered with tree canopy/total no. quarter cells in bird plot). Field visual estimates were 2 percent lower $(-4.3$ to 0.0 percent, $\mathrm{t}=-2.30, \mathrm{p}=0.0503)$ than the DOQ estimates.

In each vegetation subplot, we visually estimated percent cover of bare ground, litter, and plants $<50 \mathrm{~cm}$ tall within a 1x1-m quadrat frame. We randomly selected the location of each quadrat by selecting an azimuth and a distance between 0 and $5 \mathrm{~m}$ with a random numbers table.

Vegetation measurements were averaged across the four vegetation subplots to describe vegetation characteristics per bird plot. We converted tree and stem counts to density per hectare. At each bird plot, we followed a plotless distance method to determine an index of aggregation (A1 = $\left.\left(\left(\Sigma \mathrm{d}^{2} / \mathrm{d}^{\prime 2}\right) / \mathrm{n}\right)-0.5\right)$, where $\mathrm{d}=$ distance to the nearest tree, $\mathrm{d}^{\prime}=$ distance to next-nearest tree, and $\mathrm{n}=$ sample size. Distribution is patchy if A1 >0, random if A1 =0, uniform if A1 <0 (Holgate, 1965).

\section{Bird Sampling}

We conducted bird counts at each station on five occasions during May and June of 2005 (pretreatment) and 2006 (posttreatment), using variable circular plots (Reynolds and others, 1980) truncated at $100-\mathrm{m}$ radius. Observers were trained and tested in local bird identification and distance estimation at the beginning of the season. Observers waited for 1 minute upon arriving at each station before recording detections. Species identification and distance from the station were recorded for all birds detected (visually or aurally) within the 100-m-radius bird plot over a period of $5 \mathrm{~min}$. Visits to each bird plot were generally about 1 week apart, between sunrise and 10 a.m. In the pretreatment surveys, two observers alternated visits in order to minimize observer bias. One observer conducted all posttreatment surveys. No counts were conducted during rain or high winds. We varied the sampling order of plots to minimize temporal bias.

\section{Data Analysis}

Differences in vegetation measurements were tested among years with matched pairs t-tests. Avian species richness was calculated by summing the number of species detected on each plot over each year. We estimated the mean difference between years by treatment type (mechanically thinned or control), then tested for treatment effect with a two-sample t-test.

We excluded from further analysis bird species that made up fewer than 1 percent of the total observations or that were observed only once in either year. Because Gray Flycatchers (Empidonax wrightii) were detected only on the control plots, we were unable to assess for effects of thinning treatment on this species. We did not have sufficient observations to determine detection functions using distance sampling (Buckland and others, 2001); therefore, we calculated mean relative abundance for each bird species at each plot (total no. detections/effort) for each year. Relative abundance assumes equal probability of detection. We analyzed relative abundance of bird species characterized as pinyonjuniper specialists and of the most abundant species from each of four nesting guilds (tree nester, cavity nester, shrub nester, ground nester). We considered Black-headed Grosbeak (Pheucticus melanocephalus) a shrub-nester in our analysis, because there were no deciduous trees on our plots and Gambel oak was present in shrub form only. We determined treatment effect for each bird species and group using two-sample t-tests on the mean difference in relative abundance between years.

We modeled occupancy for the same species above plus two species that were detected in treatment plots only after treatment and one species that was no longer detected in plots following treatment. To identify variation in the probability of occupancy $(\Psi)$ at any given plot due to mechanical thinning, we modeled occupancy for each species with the following covariates: year, mechanical thinning or control, and the interaction of year and treatment assignment. We used Akaike information criterion (AIC) for model selection. If the model with the lowest AIC rating (top model) or competing 
models $(\triangle \mathrm{AIC} \leq 2)$ included occupancy probability values dependent on the interaction covariate, and the otherwise identical model without the interaction covariate was not a competing model, we inferred an effect of thinning on occupancy for that species. To identify variation in detection probability due to treatment (p), we followed Mackenzie and others (2006) in summing AIC weights from all models that included a covariate to determine the most influential covariate(s) on $\Psi$ and $\mathrm{p}$.

\section{Results}

\section{Vegetation}

The mechanical thinning treatment occurred April 10-16, 2006 (fig. 3). Treatment units were cut with power saws, and downed trees left in place where they fell. Snags and shrubs were not cut. Following mechanical thinning, tree stem density decreased between 49 and 100 percent $(\bar{d}=92$ percent, $\mathrm{SE}=6$ percent) on the treated plots and canopy cover decreased between 57 and 100 percent ( $\bar{d}=92$ percent, $\mathrm{SE}=5$ percent). Table 10 summarizes changes in tree characteristics due to mechanical thinning.

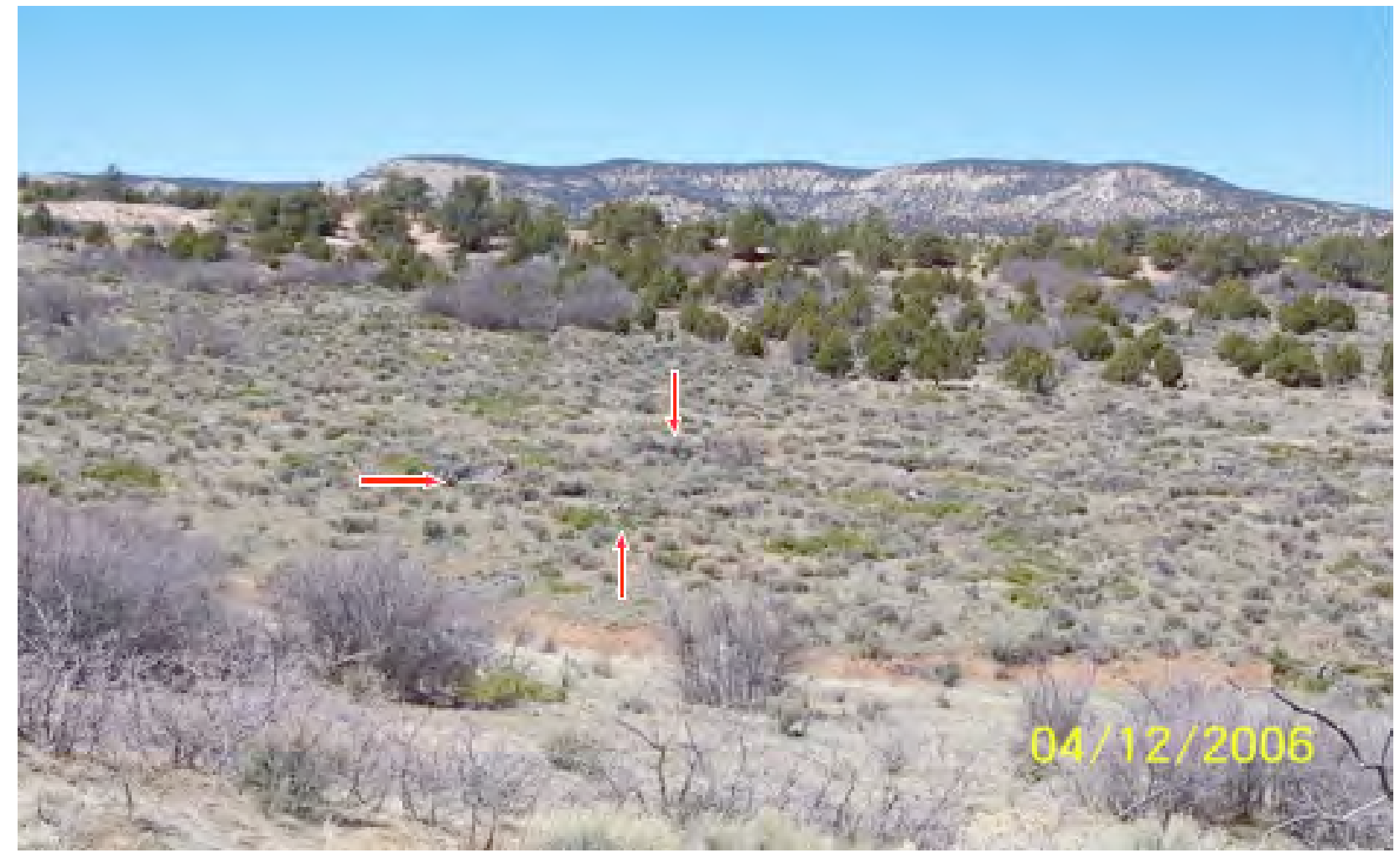

00Figure 3. Posttreatment mechanically thinned pinyon-juniper block, April 2006, Ford Pasture, Grand StaircaseEscalante National Monument, Utah. Arrows indicate down trees in treatment area showing condition of the vegetation following lop-and-drop treatment. For comparison, a control treatment block is on the far, adjacent hill. 
Table 10. Change in tree (pinyon pine and juniper combined) characteristics on nine bird plots due to mechanical-thinning treatment.

$[\mathrm{SE}=$ standard error; $\mathrm{p}=$ probability $]$

\begin{tabular}{llcrc}
\hline \multicolumn{1}{c}{ Vegetation characteristic } & Range & $\begin{array}{c}\text { Mean } \\
\text { Change }\end{array}$ & SE & p \\
\hline Trees removed (\%) & $49-100$ & 92 & 6.4 & 0.0842 \\
Distance to nearest pinyon (m) & $0-149$ & 44 & 18.0 & 0.0402 \\
Distance to nearest juniper (m) & $0-200$ & 62 & 28.4 & 0.0619 \\
\hline
\end{tabular}

\section{Breeding Birds}

Over two breeding seasons, we detected 48 bird species (table 11), 63 percent of which were summer residents, 32 percent year-round residents, and 5 percent transient species. Those species with relatively high numbers of detections included Spotted Towhee (Pipilo maculates), Brewer's Sparrow (Spizella breweri), Chipping Sparrow (Spizella passerina), Vesper Sparrow (Pooecetes graminius), and Blue-gray Gnatcatcher (Polioptila caerulea). Some species characterized as pinyon-juniper specialistsfor example, Juniper Titmouse (Baeolophus griseus) — were absent during the entire study and are probably not residents of our study area. 
[Table 11. Avian species, U.S. Geological Survey Banding Laboratory alpha code, and number of detections on 20 plots in Ford Pasture Fuels Reduction proiect area. Mav-June 2005 and Mav-June 2006.

\begin{tabular}{|c|c|c|c|}
\hline Common Name & Scientific Name & Code & Detections \\
\hline Ash-throated Flycatcher & Myiarchus cinerascens & ATFL & 63 \\
\hline Hummingbird & Archilochus alexandri & $\mathrm{BCHU}$ & 4 \\
\hline Black-crowned Sparrow & Spizella atrogularis & BCSP & 1 \\
\hline Black-headed Grosbeak & Pheucticus melanocephalus & BHGR & 45 \\
\hline Black-throated Gray & & & \\
\hline Warbler & Dendroica nigrescens & BTYW & 26 \\
\hline Black-throated Sparrow & Amphispiza bilineata & BTSP & 8 \\
\hline Blue-gray Gnatcatcher & Polioptila caerulea & BGGN & 105 \\
\hline Brewer's Sparrow & Spizella breweri & BRSP & 160 \\
\hline Brown-headed Cowbird & Molothrus ater & $\mathrm{BHCO}$ & 7 \\
\hline Bushtit & Psaltriparus minimus & BUSH & 36 \\
\hline Cassin's Kingbird & Tyrannus vociferans & CAKI & 2 \\
\hline Chipping Sparrow & Spizella passerina & CHSP & 119 \\
\hline Common Nighthawk & Cordeiles minor & CONI & 2 \\
\hline Common Poorwill & Phalaenoptilus nuttallii & $\mathrm{COPO}$ & 0 \\
\hline Common Raven & Corvus corax & CORA & 0 \\
\hline Dark-eyed Junco & Junco hyemalis & DEJU & 2 \\
\hline Gray Flycatcher & Empidonax wrightii & GRFL & 7 \\
\hline Gray Vireo & Vireo vicinior & GRVI & 11 \\
\hline Green-tailed Towhee & Pipilo chlorurus & GTTO & 1 \\
\hline Hairy Woodpecker & Picoides villosus & HAWO & 1 \\
\hline House Finch & Carpodacus mexicanus & HOFI & 9 \\
\hline Lark Sparrow & Chondestes grammacus & LASP & 22 \\
\hline Lazuli Bunting & Passerina amoena & LAZB & 2 \\
\hline Lincoln's Sparrow & Melospiza lincolnii & LISP & 2 \\
\hline Long-billed Curlew & Numenius americanus & LBCU & 1 \\
\hline Mountain Bluebird & Sialia currucoides & MOBL & 14 \\
\hline Mountain Chickadee & Poecile gambeli & $\mathrm{MOCH}$ & 1 \\
\hline Mourning Dove & Zenaida macroura & MODO & 37 \\
\hline Northern Flicker & Colaptes auratus & NOFL & 4 \\
\hline Northern Harrier & Circus cyaneus & NOHA & 1 \\
\hline Northern Mockingbird & $\begin{array}{l}\text { Mimus polyglottos } \\
\text { Gymnorhinus }\end{array}$ & NOMO & 7 \\
\hline Pinyon Jay & cyanocephalus & PIJA & 0 \\
\hline Red-tailed Hawk & Buteo jamaicensis & RTHA & 3 \\
\hline Sage Sparrow & Amphispiza belli & SAGS & 3 \\
\hline Say's Phoebe & Sayornis saya & SAPH & 5 \\
\hline Spotted Towhee & Pipilo maculatus & SPTO & 311 \\
\hline Townsend's Solitaire & Myadestes townsendi & TOSO & 5 \\
\hline Turkey Vulture & Cathartes aura & TUVU & 0 \\
\hline
\end{tabular}




\begin{tabular}{lllr} 
Vesper Sparrow & Pooecetes graminius & VESP & 101 \\
Violet-green Swallow & Tachycineta thalassina & VGSW & 2 \\
Virginia's Warbler & Vermivora virginiae & VIWA & 4 \\
Western Bluebird & Sialia mexicana & WEBL & 59 \\
Western Meadowlark & Sturnella neglecta & WEME & 29 \\
Western Tanager & Piranga ludoviciana & WETA & 3 \\
Wild Turkey & Melagris gallopavo & WITU & 0 \\
Western Scrub-jay & Aphelocoma californica & WSJA & 16 \\
Yellow-rumped Warbler & Dendroica coronata & YRWA & 4 \\
\hline
\end{tabular}

Avian community composition did change as a result of treatment, but bird species richness did $\operatorname{not}\left(\mathrm{t}_{15}=0.11, \mathrm{p}=0.9129\right)$ (table 12). The Gray Vireo and Brown-headed Cowbird were no longer detected on the treatment plots after mechanical thinning, and of the 14 species that we considered, after accounting for all nontreatment factors we found evidence of a significant influence of mechanical thinning on site occupancy of these 2 species (table 13). Differences in pretreatment and posttreatment site occupancy in Black-headed Grosbeak (Pheucticus melanocephalus) were better explained by variation in occupancy between years (46 percent summed AIC weight) and between thinning and control units ( 46 percent summed AIC weight), than by the influence of the mechanical thinning (27 percent of summed AIC weight). Site occupancy of the remainder of species that we analyzed was not influenced by mechanical thinning.

Table 12. Species richness (measured as total number of bird species) from pretreatment and posttreatment bird surveys on mechanical-thinning and control plots.

$[\mathrm{SE}=$ standard error $]$

\begin{tabular}{l|c|c|c|c}
\hline \multirow{2}{*}{ Treatment Assignment } & \multicolumn{2}{|c|}{ Pretreatment } & \multicolumn{2}{c}{ Posttreatment } \\
\cline { 2 - 5 } & Mean & SE & Mean & SE \\
\hline Mechanical-thinning & 9.6 & 1.9 & 9.8 & 1.3 \\
Control & 9.7 & 1.5 & 10.0 & 1.8 \\
\hline
\end{tabular}


Table 13. Site occupancy: summed AIC weights of occupancy probability $(\Psi)$ and detection probability $(p)$ covariates for avian species.

[Weights were not summed for Gray Vireo and Brown-headed Cowbird, for which effect of mechanical thinning on occupancy, denoted by the interaction covariate (trtyrint), was an element of the model with the lowest and second-lowest AIC values, respectively; trt = treatment assignment (treat or control); yr = year]

\begin{tabular}{l|ccc|ccc}
\hline \multirow{2}{*}{ Species } & \multicolumn{3}{|c|}{ Site Occupancy } & \multicolumn{3}{c}{ Detectability } \\
\cline { 2 - 7 } BGGN & $\boldsymbol{\psi}$ (trtytint) & $\boldsymbol{\psi}$ (trt) & $\boldsymbol{\psi}(\mathbf{y r})$ & $\mathrm{p}$ (trtyrint) & $\mathbf{p}$ (trt) & $\mathrm{p}$ (yr) \\
BTYW & $0 \%$ & $26 \%$ & $0 \%$ & $0 \%$ & $71 \%$ & $18 \%$ \\
GRVI & $0 \%$ & $0 \%$ & $0 \%$ & $23 \%$ & $82 \%$ & $76 \%$ \\
WSJA & top model & $\mathrm{N} / \mathrm{A}$ & $\mathrm{N} / \mathrm{A}$ & $\mathrm{N} / \mathrm{A}$ & $\mathrm{N} / \mathrm{A}$ & $\mathrm{N} / \mathrm{A}$ \\
BHGR & $0 \%$ & $36 \%$ & $30 \%$ & $15 \%$ & $33 \%$ & $36 \%$ \\
BRSP & $27 \%$ & $46 \%$ & $46 \%$ & $58 \%$ & $77 \%$ & $76 \%$ \\
CHSP & $0 \%$ & $0 \%$ & $0 \%$ & $59 \%$ & $0 \%$ & $0 \%$ \\
MODO & $0 \%$ & $25 \%$ & $0 \%$ & $27 \%$ & $96 \%$ & $46 \%$ \\
ATFL & $0 \%$ & $0 \%$ & $0 \%$ & $19 \%$ & $43 \%$ & $80 \%$ \\
SPTO & $0 \%$ & $25 \%$ & $0 \%$ & $20 \%$ & $75 \%$ & $41 \%$ \\
VESP & $0 \%$ & $0 \%$ & $0 \%$ & $42 \%$ & $59 \%$ & $75 \%$ \\
BHCO & $0 \%$ & $0 \%$ & $0 \%$ & $32 \%$ & $100 \%$ & $98 \%$ \\
BUSH & competing & N/A & N/A & N/A & N/A & N/A \\
NOMO & $0 \%$ & $33 \%$ & $0 \%$ & $0 \%$ & $42 \%$ & $23 \%$ \\
\hline
\end{tabular}

${ }^{1}$ See table 11 for species codes and names.

Three species were detected on treatment plots only after treatment, and two species were no longer detected on treatment plots after mechanical thinning (table 14). Because Northern Mockingbird (Mimulus polyglottus) was not detected on treatment or control plots before treatment, but was detected on both treatment and control plots after thinning, treatments cannot be responsible for the appearance of this species on the study plots. Differences in pretreatment and posttreatment detection probability for Black-throated Gray Warbler (table 13) were better explained by variation in detection probability between years (76 percent summed AIC weight) and between thinning and control units ( 82 percent summed AIC weight) than by the influence of the mechanical thinning ( 23 percent summed AIC weight). Probability of occupancy detection of the remaining three species was not influenced by mechanical thinning. 
Table 14. Percent of control and treatment plots on which five species were detected before and after thinning of pinyon-juniper woodlands.

\begin{tabular}{l|c|c|c|c}
\hline \multirow{2}{*}{ Species } & \multicolumn{2}{|c|}{ Control Plots } & \multicolumn{2}{c}{ Treatment Plots } \\
\cline { 2 - 5 } & Pre & Post & Pre & Post \\
\hline BTYW & 55 & 64 & 0 & 11 \\
GRVI & 0 & 45 & 33 & 1 \\
BHCO & 0 & 36 & 11 & 1 \\
BUSH & 18 & 18 & 0 & 56 \\
NOMO & 0 & 22 & 0 & 11 \\
\hline
\end{tabular}

${ }^{1}$ See table 11 for species codes and names.

There was evidence of an effect of mechanical thinning on mean relative abundance of 3 of 11 bird species (table 15). Gray Vireo and Chipping Sparrow abundance decreased in response to treatment, relative to controls. Brewer's Sparrow increased in abundance after treatment, as did shrubnesters as a group.

Table 15. Mean difference in mean relative abundance and outcomes of two-sample t-tests for treatment effect on the mean difference in relative abundance (2006-2005) on control plots ( $\Delta$ Control) vs. the mean difference in relative abundance on treatment plots ( $\Delta$ Treatment) for pinyon-juniper specialists (PJ) and other common species, by group (PJ or nesting guild) and by species.

$[\mathrm{SE}=$ standard error; $\mathrm{y}=\mathrm{Y}$ value; $\mathrm{df}=$ degrees of freedom; $\mathrm{p}=$ probability $]$

\begin{tabular}{|c|c|c|c|c|c|c|c|c|c|c|}
\hline \multirow[b]{3}{*}{ Guild } & \multirow[b]{3}{*}{ Species $^{1}$} & \multicolumn{4}{|c|}{ Difference (2006-2005) } & \multirow{2}{*}{\multicolumn{5}{|c|}{$\begin{array}{c}\text { Effect of Mechanical Thinning } \\
(\Delta \text { Treatment })-(\Delta \text { Control }\end{array}$}} \\
\hline & & \multicolumn{2}{|c|}{ Control } & \multicolumn{2}{|c|}{ Treatment } & & & & & \\
\hline & & $y$ & SE & $y$ & SE & $y$ & SE & df & $\mathrm{t}$ & $\mathrm{p}$ \\
\hline PJ & Group & 0.1 & 0.06 & -0.01 & 0.03 & 0.1 & 0.07 & 71 & 1.69 & 0.0949 \\
\hline PJ & BGGN & 0.0 & 0.16 & 0.1 & 0.11 & 0.1 & 0.19 & 17 & 1.48 & 0.6387 \\
\hline PJ & BTYW & 0.1 & 0.10 & 0.0 & 0.02 & -0.1 & 0.10 & 11 & 1.01 & 0.3355 \\
\hline PJ & GRVI & 0.1 & 0.05 & -0.1 & 0.05 & -0.2 & 0.07 & 18 & 3.14 & 0.0057 \\
\hline PJ & WSJA & 0.2 & 0.1 & -0.1 & 0.08 & -0.3 & 0.15 & 17 & 1.55 & 0.1400 \\
\hline Shrub & Group & -0.1 & 0.1 & 0.3 & 0.1 & 0.4 & 0.19 & 28 & -1.94 & 0.0618 \\
\hline Shrub & BHGR & 0.2 & 0.91 & 0.2 & 0.06 & 0.0 & 0.11 & 17 & 1.23 & 0.8173 \\
\hline Shrub & BRSP & -0.4 & 0.12 & 0.3 & 0.33 & 0.7 & 0.36 & 10 & -2.04 & 0.0686 \\
\hline Tree & Group & 0.2 & 0.11 & -0.1 & 0.11 & -0.3 & 0.16 & 37 & 1.17 & 0.2500 \\
\hline Tree & CHSP & 0.2 & 0.20 & -0.3 & 0.17 & -0.5 & 0.27 & 18 & 1.89 & 0.0753 \\
\hline Tree & MODO & 0.1 & 0.09 & 0.2 & 0.09 & 0.1 & 0.13 & 18 & -1.05 & 0.3063 \\
\hline Cavity & ATFL & -0.1 & 0.09 & 0.1 & 0.11 & -0.2 & 0.14 & 16 & -1.54 & 0.1443 \\
\hline Ground & Group & -0.1 & 0.10 & 0.6 & 0.10 & 0.2 & 0.14 & 55 & -1.10 & 0.2773 \\
\hline Ground & SPTO & 0.3 & 0.19 & 0.7 & 0.07 & 0.4 & 0.21 & 13 & -1.66 & 0.1201 \\
\hline Ground & VESP & -0.3 & 0.12 & -0.4 & 0.13 & -0.1 & 0.18 & 18 & 0.76 & 0.4589 \\
\hline
\end{tabular}

${ }^{\mathrm{T}} \mathrm{See}$ table 11 for species codes and names. 


\section{Discussion}

Changes in community composition occur when species are either no longer found in an area where they were once present or are initially found where they were previously absent. Gray Vireo was eliminated from treated units as a result of mechanical thinning, which is consistent with previous studies showing that this pinyon-juniper obligate breeds in open, mature pinyon-juniper, juniper-oak, and juniper-dominated woodlands (Balda and Masters, 1980; Latta and others, 1999; Parrish and others, 2002). This species nests in shrubs or junipers (Ehrlich and others, 1988; Parrish and others, 2002). Previous research on the Colorado Plateau showed that Gray Vireo was absent in pinyon-juniper woodlands where trees had been killed by fire but was using adjacent pinyon-juniper woodlands which had not burned (Schlossberg, 2006). Positive associations have been found between density of Gray Vireo and ratio of junipers to pinyon pines (Schlossberg, 2006). Clearly, the trees in pinyon-juniper woodlands are important to this species, although the exact nature of the relation is not known. There is little detailed knowledge about the life history and habitat requirements of the Gray Vireo, possibly because of sparse distribution of small pockets of local abundance, or because of its secretive behavior (Parrish and others, 2002).

Brown-headed Cowbird, which is known to parasitize the nests of Gray Vireo (Latta and others, 1999), was also eliminated from treatment plots as a result of mechanical thinning. Removal of trees and creation of "edge" through management activities have been implicated, along with cattle grazing, in the spread of Brown-headed Cowbird distribution throughout the United States (Lowther, 1993). This species prefers wooded areas near the interface with fields or shrubs (Gates and Evans, 1998). In the present study, Brown-headed Cowbird was found in untreated areas bounding the mechanically thinned units after thinning. Female Cowbirds require perches from which to observe other avian species to find nests to parasitize (Ehrlich and others, 1988). A positive association has been found between the number of tall perches available and the frequency of cowbird parasitism of Black-throated Sparrows in central Arizona (Johnson and van Riper, 2004). Removal of 49 to 100 percent of the trees in the mechanically thinned units at Ford Pasture may have rendered treated areas less desirable to female Cowbirds. Alternatively, changes in the distribution of hosts may have influenced changes in the distribution of Cowbirds. Gray Vireo and Chipping Sparrow are frequent Cowbird hosts, and Brown-headed Cowbirds may concentrate on one host species at a local level (Ehrlich and others, 1988).

Relative abundance of Chipping Sparrow decreased following mechanical thinning. Previous studies found this species to be associated with pinyon-juniper woodland edges and other moderately open areas, including natural openings in mature woodlands (Pavlacky and Anderson, 2004; Sedgwick, 1987). Chipping Sparrow foraged and nested in chained plots 3 to 4 years after treatment but did not use chained areas more than $100 \mathrm{~m}$ from the treatment boundary (O'Meara and others, 1981; Sedgwick and Ryder, 1987). Because Chipping Sparrow nests in conifers and deciduous trees (Ehrlich and others, 1988), treatments that significantly reduce the number of trees available for nesting are likely to have negative impacts on this species.

Relative abundance of Brewer's Sparrow increased following mechanical thinning, which corresponds with previous findings that Brewer's Sparrow prefers relatively open areas with large shrubs and low tree density and height within early successional pinyon-juniper woodlands (Pavlacky and Anderson, 2004; Sedgwick 1987) and in other vegetation communities (Rotenberry and Wiens, 1980; Wiens, 1985). This species used chained areas at the interior of the treatment (Sedgwick, 1987) and was found exclusively on chained plots in one study (O'Meara and others, 1981). Brewer's Sparrow has been identified as a shrub-steppe obligate which nests nearly exclusively in sagebrush, including large sagebrush openings in pinyon-juniper woodlands (Parrish and others, 2002; Rotenberry and 
others, 1999; Sedgwick, 1987). Mechanical thinning appears to have increased breeding habitat quality, hence posttreatment areas supported a larger number of nesting Brewer's Sparrows.

The relative abundance of shrub nesters as a group increased after mechanical thinning. This finding possibly reflects a reduction in competition with tree nesters for nontree resources. The occupancy probabilities of the species in this group were not influenced by thinning.

Relative abundance of pinyon-juniper specialists as a group did not change in the treatment units. However, there is some indication that the group's abundance decreased in the controls yet remained the same in treatment units $(\mathrm{p}=0.0949)$. Because we investigated responses only in the breeding season immediately following treatment, we suggest that over time abundance in this group could decrease significantly.

Thinning reduced the complexity of vegetation structure by removing most of the trees (fig. 3). Even with this vegetation change, bird species richness did not change as a result of the thinning treatment. Previous studies have shown a relationship between structural complexity of vegetation and bird species richness (Karr, 1968; Karr and Roth, 1971; MacArthur and others, 1962). Thinning treatments that selectively remove only a portion of the trees in dense stands would increase structural diversity. In the present study, we expect that bird species richness may decrease over the next few years, as species continue to respond to the vegetation changes.

Overall, there did not seem to be much difference in response between bird species with specific pinyon-juniper or shrub requirements and other species. One pinyon-juniper specialist and one brood parasite were eliminated, one tree-nester decreased in abundance, and one shrub-nester increased in abundance. The group response of shrub-nesters appeared to be driven by Brewer's Sparrow numbers. Again, long-term responses may be more extreme than the immediate responses documented in this study.

\section{References Cited}

Anderson, S.H., and Shughart, H.H., 1974, Habitat selection of breeding birds in an east Tennessee deciduous forest: Ecology, v. 55, p. 828-837.

Balda, R.P., 1987, Avian impacts on pinyon-juniper woodlands, in Everett, R.L., ed., Proceedings Pinyon Juniper Conference: Ogden, Utah, U.S. Department of Agriculture Forest Service Intermountain Research Station, General Technical Report INT-125, p. 525-533.

Balda, R.P., and Masters, N., 1980, Avian communities in the pinyon-juniper woodland; a descriptive analysis, in Workshop proceedings; management of western forests and grasslands for nongame birds: Ogden, Utah, U.S. Department of Agriculture Forest Service Intermountain Research Station, General Technical Report INT-86, p. 146-169.

Bock, C.E., and Block, W.M., 2005, Fire and birds in the southwestern United States: Studies in Avian Biology, v. 30, p. 14-32.

Bradshaw, K.E., and Reveal, J.L., 1943, Tree classifications for Pinus monophylla and Juniperus utahensis: Journal of Forestry, v. 41, p. 100-104.

Breshears, D.D., Cobb, N.S., Rich, P.M., Price, K.P., Allen, C.D., Balice, R.G., Romme, W.H., Kastens, J.H., Floyd, M.L., Belnap, J., Anderson, J.J., Myers, O.B., and Meyer, C.W., 2005, Regional vegetation die-off in response to global-change type drought: Proceedings of the National Academy of Science, v. 102, p. 15144-15148.

Brown, B.T., 1992, Nesting chronology, density and habitat use of Black-chinned Hummingbirds along the Colorado River, Arizona: Journal of Field Ornithology, v. 63, p. 393-400.

Brunson, M.W., and Shindler, B.A., 2004, Geographic variation in social acceptability of wildland fuels management in the western United States: Society and Natural Resources, v. 17, p. 661-678. 
Buckland, S.T., Anderson, D.R., Burnham, K.P., Laake, J.L., Borchers, D.L., and Thomas, L., 2001, Introduction to distance sampling: estimating abundance of biological populations: New York, Oxford University Press, p. 20-32.

Clark, J.R., 1999, The ecosystem approach from a practical point of view: Conservation Biology, v. 13, p. 679-681.

deHoop, C.F., Reddy, A.H., and Smith, R., 2006, Forest fuel reduction survey analysis; forest administrators: Baton Rouge, La., Louisiana Agricultural Experiment Station, Louisiana Forest Products Development Center Working Paper 73, p. 2-15.

Dombeck, M., 1996, Thinking like a mountain; BLM's approach to ecosystem management: Ecological Applications, v. 6, p. 699-702.

Ehrlich, P.R., Dobkin, D.S., and Wheye, D., 1988, The birder's handbook; a field guide to the natural history of North American birds: New York, Simon and Schuster, p. 328-646.

Gates, J.E., and Evans, D.R., 1998, Cowbirds breeding in the central Appalachians; spatial and temporal patterns and habitat selection: Ecological Applications, v. 8, p. 27-40.

Goguen, C.B., Curson, D.R., and Matthews, N.E., 2005, Breeding ecology of the Gray Flycatcher in pinyon-juniper woodlands in New Mexico: Western Birds, v. 36, p. 286-295.

Gray, S.T., Betancourt, J.L., Jackson, S.T., and Eddy, R.G., 2006, Role of multidecadal climate variability in a range extension of pinyon pine: Ecology, v. 87, p. 1124-1130.

Hardy, R., 1945, Breeding birds of the pigmy conifers in the Book Cliff region of eastern Utah: Auk, v. 62 , p. 523-542.

Harper, K.T., Sanderson, S.C., and McArthur, E.D., 2003, Pinyon-juniper woodlands in Zion National

Park, Utah: Western North American Naturalist, v. 63, p. 189-202.

Harris, A.T., Asner, G.P., and Miller, M.E., 2003, Changes in vegetation structure after long-term grazing in pinyon-juniper ecosystems; integrating imaging spectroscopy and field studies: Ecosystems, v. 6, p. 368-383.

Holgate, P., 1965, Some new tests of randomness: The Journal of Ecology, v. 53, p. 261-266.

James, F.C., 1971, Ordinations of habitat relationships among breeding birds: Wilson Bulletin, v. 83, p. 215-236.

Johnsen, T.N., 1962, One-seed juniper invasion of northern Arizona grasslands: Ecological Monographs, v. 32, p. 187-207.

Johnson, M.J., and van Riper, C., III, 2004, Brown-headed Cowbird parasitism of the Black-throated Sparrow in central Arizona: Journal of Field Ornithology, v. 75, p. 303-311.

Karr, J.R., 1968, Habitat and avian diversity on strip-mined land in east-central Illinois: Condor, v. 70, p. 348-357.

Karr, J.R., and Roth, R.R., 1971, Vegetation structures and avian diversity in several New World areas: American Naturalist, v. 105, p. 423-435.

Keane, J.J., and Morrison, M.L., 1999, Temporal variation in resource use by Black-throated Gray Warblers: Condor, v. 101, p. 67-75.

Knick, S.T., Holmes, A.L., and Miller, R. F., 2005, The role of fire in structuring sagebrush habitats and bird communities: Studies in Avian Biology, v. 30, p. 63-75.

Latta, M.J., Beardmore, C.J., and Corman, T.E., 1999, Arizona Partners in Flight Bird Conservation Plan, Version 1.0: Phoenix, Ariz., Arizona Game and Fish Department, Nongame and Endangered Wildlife Program Technical Report 142, p. 69-89.

Laudenslayer, W.F., Jr., and Balda, R.P., 1976, Breeding bird use of a pinyon-juniper-ponderosa pine ecotone: Auk, v. 93, p. 571-586. 
Lowther, P.E., 1993, Brown-headed Cowbird, in Birds of North America: Philadelphia, Penn., The Birds of North America, Inc., no. 47, p. 11-13.

MacArthur, R.H., MacArthur, J.W., and Preer, J., 1962, On bird species diversity: American Naturalist, v. 98, p. 387-397.

Mackenzie, D.I., Nichols, J.D., Royle, J.A., Pollock, K.H., Bailey, L.L., and Hines, J.E., 2006, Occupancy estimation and modeling: New York, Academic Press, p. 142-167.

Martin, T.E., Paine, C.R., Conway, C.J., Hochachka, W.M., Allen, P., and Jenkins, W., 1997, BBIRD field protocol: Missoula, Mont., University of Montana, Montana Cooperative Wildlife Research Unit, p. 5-44.

Medin, D.E., Welch, B.L., and Clary, W.P., 2000, Bird habitat relationships along a Great Basin elevational gradient: Fort Collins, Colo., U.S. Department of Agriculture Forest Service Rocky Mountain Research Station, Research Paper RMRS-RP-23, p. 6.

Miller, R.F., and Rose, J.A., 1999, Fire history and western juniper encroachment in sagebrush steppe: Journal of Range Management, v. 52, p. 550-559.

Miller, R.F., and Wigand, P.E., 1994, Holocene changes in semiarid pinyon-juniper woodlands: Bioscience, v. 44, p. 465-474.

Moir, W.H., and Carton, J.D., 1987, Classification of pinyon-juniper (P-J) sites on national forests in the southwest, in Everett, R.L., ed., Proceedings, Pinyon Juniper Conference: Ogden, Utah, U.S. Department of Agriculture Forest Service Intermountain Research Station, General Technical Report INT-125, p. 216-225.

O’Meara, T.E., Haufler, J.B., Stelter, L.H., and Nagy, J.G., 1981, Nongame wildlife responses to chaining of pinyon-juniper woodlands: Journal of Wildlife Management, v. 46, p. 381-389.

Parrish, J.R., Howe, F.P., and Norvell, R.E., 2002, Utah Partners in Flight Avian Conservation Strategy, version 2.0: Salt Lake City, Utah, Utah Division of Wildlife Resources, Utah Partners in Flight Program, UDWR Publication 20-27, 302 p.

Pavlacky, D.C., and Anderson, S.H., 2001, Habitat preferences of pinyon-juniper specialists near the limit of their geographic range: Condor, v. 103, p. 322-331.

Pavlacky, D.C., and Anderson, S.H., 2004, Comparative habitat use in a juniper woodland bird community: Western North American Naturalist, v. 64, p. 376-384.

Poddar, S,. and Lederer, R.J., 1982, Juniper berries as an exclusive winter forage for Townsend's Solitaires: American Midland Naturalist, v. 108, p. 34-40.

Ramsey, F.L., and Schafer, D.W., 2002, The statistical sleuth: Pacific Grove, Calif., Duxbury Press, p. 623-698.

Reed, J.M., 1986, Vegetation structure and vesper sparrow territory location: Wilson Bulletin, v. 98, p. 144-147.

Reynolds, R.T., Scott, J.M., and Nussbaum, R.A., 1980, A variable circular-plot method for estimating bird numbers: Condor, v. 82, p. 309-313.

Rosenstock, S.S., and van Riper, C., III, 2001, Breeding bird responses to juniper woodland expansion: Journal of Range Management, v. 54, p. 226-232.

Rotenberry, J.T., Patten, M.A., and Preston, K.L., 1999, Brewer's Sparrow (Spizella brewerii), in Poole, A., and Gill, F., eds., Birds of North America: Philadelphia, Penn., The Birds of North America, Inc., no. 390, p. 4-5.

Rotenberry, J.T., and Wiens, J.A., 1980, Habitat structure, patchiness, and avian communities in North American steppe vegetation; a multivariate analysis: Ecology, v. 61, p. 1228-1230.

Ryser, F.A., Jr., 1985, Birds of the great basin; A natural history: Reno, Nev., University of Nevada Press. 
Samuels, M.L., and Betancourt, J.L., 1982, Modeling the long-term effects of fuelwood harvests on pinyon-juniper woodlands: Environmental Management, v. 6, p. 505-515.

Schlossberg, S., 2006, Abundance and habitat preferences of Gray Vireos (Vireo vicinior) on the Colorado Plateau: Auk, v. 123, p. 33-44.

Sedgwick, J.A., 1987, Avian habitat relationships in pinyon-juniper woodland: Wilson Bulletin, v. 99, p. 413-431.

Sedgwick, J.A., and Ryder, R.A., 1987, Effects of chaining pinyon-juniper on nongame wildlife, in Everett, R.L., ed., Proceedings, Pinyon Juniper Conference: Ogden, Utah, U.S. Department of Agriculture Forest Service Intermountain Research Station, General Technical Report INT-125, p. 541-551.

Shindler, B., 2004, Public acceptance of wildland fire conditions and fuel reduction practices; challenges for federal forest managers, http://www.oregonstate.edu/ shindleb/jfsp/Public_Acceptance.pdf (last accessed Jan. 21, 2011), p. 214.

Stauffer, D.F., and Best, L.B., 1980, Habitat selection by birds of riparian communities: evaluating effects of habitat alterations: Journal of Wildlife Management, v. 44, p. 1-15.

Tausch, R.J., 1999, Historic woodland development, in Monsen, S.B., Stevens, R., Tausch, R.J., Miller, R., and Goodrich, S., eds., Proceedings, ecology and management of pinyon-juniper communities within the interior west: Ogden, Utah, U.S. Department of Agriculture Forest Service Rocky Mountain Research Station, p. 12-19.

Tausch, R.J., and Hood, S.M., 2007, Pinyon-juniper woodlands, in Hood, S.M., and Miller, M., eds., Fire ecology and management of the major ecosystems of southern Utah: Fort Collins, Colo., U.S. Department of Agriculture Forest Service Rocky Mountain Research Station, General Technical Report RMRS-GTR-202, p. 57-72.

U.S. Department of Agriculture Forest Service, 1994, Neotropical migratory bird reference book: San Francisco, Calif., U.S. Department of Agriculture Forest Service Region 5,p. 12-14.

U.S. Department of Agriculture Forest Service, 1996, Landbird Monitoring Implementation Plan: San Francisco, Calif., U.S. Department of Agriculture Forest Service Region 5, p. 48-50.

U.S. Department of Agriculture Forest Service and Bureau of Land Management, 2004, The Healthy Forests Initiative and Healthy Forests Restoration Act interim field guide: Washington, D.C., U.S. Department of Agriculture Forest Service, FS-799.

U.S. Department of Agriculture Forest Service and U.S. Fish and Wildlife Service, 2001, Memorandum of understanding between U.S. Department of Agriculture Forest Service and U.S. Fish and Wildlife Service: 01-MU-11130117-028.

U.S. Department of the Interior and U.S. Department of Agriculture Forest Service, 2006, Protecting People and Natural Resources: a cohesive fuels treatment strategy, U.S. Department of the Interior and USDA Forest Service, Washington, D.C.

Wauer, R., 1997, Birds of Zion National Park and Vicinity: Logan, Utah., Utah State University Press,p. 157-158.

West, N. E., 1984, Successional patterns and productivity potentials of pinyon-juniper ecosystems, in National Research Council/National Academy of Sciences, eds., Developing strategies for rangeland management: Boulder, Colo., Westview Press, p. 1301-1322.

West, N.E., Tausch, R.J., Tueller, P.T., 1998, A management oriented classification of pinyon-juniper woodlands of the Great Basin: Ogden, Utah., U.S. Department of Agriculture Forest Service Rocky Mountain Research Station, General Technical Report RMRS-GTR-12, p. 1. 
Wethington, S.M., and Russell, S.M., 2003, The seasonal distribution and abundance of hummingbirds in oak woodland and riparian communities in southeastern Arizona: Condor, v. 105, p. 484-495.

Whitmore, R.C., 1975, Habitat ordination of passerine birds of the Virgin River Valley, southwestern Utah: Wilson Bulletin, v. 87, p. 65-74.

Wiens, J.A., 1985, Habitat selection in variable environments; shrub-steppe birds, in Physiological ecology; habitat selection in birds: Orlando, Fla., Academic Press, p. 227-251.

Wray, T., II, and Whitmore, R.C., 1979, Effects of vegetation on nesting success of Vesper Sparrows: Auk, v. 96, p. 802-805.

Willson, M.F., 1974, Avian community organization and habitat structure: Ecology, v. 55, p. 10171029. 
This page intentionally left blank 
